\title{
Calcification rate and shell chemistry response of the planktic foraminifer Orbulina universa to changes in microenvironment seawater carbonate chemistry
}

Kate Holland ${ }^{1}$, Stephen M. Eggins ${ }^{1}$, Bärbel Hönisch ${ }^{2}$, Laura L. Haynes ${ }^{2}$ and Oscar Branson ${ }^{1}$

\begin{abstract}
We use LA-ICP-MS depth profiling to explore the sensitivity of shell chemistry of the symbiotic planktic foraminifer Orbulina universa to diurnal changes in the holobiont physiology, over a wide range of seawater $\mathrm{pH}$ and DIC compositions. B/Ca and U/Ca vary in concert with diurnal $\mathrm{Mg} / \mathrm{Ca}$ banding, forming compositional bands that are qualitatively consistent with physiological modification of seawater carbonate chemistry $\left(\mathrm{pH},\left[\mathrm{B}(\mathrm{OH})_{4}{ }^{-}\right.\right.$ $\left./ \mathrm{HCO}_{3}{ }^{-}\right]$and $\left[\mathrm{CO}_{3}{ }^{2-}\right]$ ) within the foraminiferal microenvironment by the net effects of photosynthesis, respiration and calcification. The amplitude of $\mathrm{B} / \mathrm{Ca}$ banding broadly conforms to banding predicted using the bulk-shell $\mathrm{B} / \mathrm{Ca}$ sensitivity to the carbonate chemistry changes in the foraminiferal microenvironment. U/Ca banding tends to be greater than predicted using the published bulk-shell sensitivity of this proxy to carbonate chemistry. This either suggests that carbonate chemistry changes in the foraminiferal microenvironment are greater than predicted by modelling and/or the published bulk shell calibration does not accurately reflect the U/Ca sensitivity at the micro-scale. A fourfold increase in seawater DIC composition (1026 to $4019 \mu \mathrm{mol} \mathrm{kg}^{-1}$ ) is associated with significant increases in $\mathrm{Sr} / \mathrm{Ca}$ and $\mathrm{Mg} / \mathrm{Ca}$ partitioning, and a decrease in $\mathrm{Mn} / \mathrm{Ca}$ partitioning into shell calcite. The accompanying fourfold increase in calcite saturation produces only a twofold increase in
\end{abstract}


26 calcification rate $\left(0.14\right.$ to $\left.0.28, \pm 0.02 \mu \mathrm{m} \mathrm{hr}^{-1}\right)$, suggesting that seawater carbonate chemistry

27 exerts only a small effect on foraminiferal calcification rates, but does have a significant influence on trace element incorporation at both the inter-shell and bulk-shell scale.

\section{INTRODUCTION}

The trace element and stable isotope compositions of calcium carbonate precipitated by planktic foraminifera differ significantly from inorganic calcite compositions precipitated from seawater. This includes many of the major proxies used for seawater temperature and carbonate system reconstruction $\left(\mathrm{Mg} / \mathrm{Ca}, \mathrm{B} / \mathrm{Ca}, \delta^{11} \mathrm{~B}, \delta^{18} \mathrm{O}\right.$; see Allen et al., 2011, 2012; Bijma et al., 1999; Lea et al., 1999; McCrea, 1950; Morse and Bender, 1990; Sanyal et al., 1996, 2000; Uchikawa et al., 2015). The reasons for the differences between biologically precipitated and inorganic minerals remain poorly understood and are often simply attributed to unspecified biological "vital effects" (Urey et al., 1951; Weiner and Dove, 2003). The uncertain influence of vital effects on trace element incorporation into foraminifer shells remains a significant impediment to our ability to reconstruct past seawater conditions from geochemical proxies.

In planktic foraminifera, vital effects include physiological processes (e.g., photosynthesis, respiration and calcification) that modify seawater chemistry in the external boundary layer (microenvironment), and internal processes that regulate the precipitation rate, composition, polymorph type, topology and orientation of calcium carbonate (de Nooijer et al., 2014). Several studies have documented large diurnal carbonate chemistry variations within the microenvironment of symbiotic foraminifera (Jørgensen et al., 1985; Köhler-Rink and Kühl, 2005; Rink et al., 1998), which can be explained by changes in the balance between respiration and photosynthesis of the host foraminifer and algal symbionts (Wolf-

50 Gladrow et al., 1999; Zeebe et al., 1999, 2003). Daytime photosynthetic activity of algal 
symbionts consumes $\mathrm{CO}_{2}$ and raises $\mathrm{pH}$ in the microenvironment, whereas nighttime respiration of the host foraminifer and symbionts releases $\mathrm{CO}_{2}$ and lowers $\mathrm{pH}$ in the microenvironment. This drives a large diurnal change of almost one $\mathrm{pH}$ unit adjacent to the shell surface of Orbulina universa (Köhler-Rink and Kühl, 2005; Rink et al., 1998). Seawater in the microenvironment provides the source of ions for biomineralisation (de Nooijer et al, 2014), although the chemistry of the internal calcification environment is modified by physiochemical processes used to promote or regulate calcification (Bentov et al., 2009; de Nooijer et al., 2009, Glas et al., 2012; Zeebe and Sanyal 2002). The extent of the connection between the external microenvironment and internal calcification environment is unknown, although they are certainly linked, given the architecture of the calcification site (Fig 1).

The large diurnal changes in $\mathrm{pH}$, DIC and other carbonate system parameters in the foraminiferal microenvironment (Köhler-Rink and Kühl, 2005; Rink et al., 1998; WolfGladrow et al., 1999) have the potential to influence and modify the incorporation of $\mathrm{pH}-$ and carbonate-system sensitive trace elements such as $\mathrm{B} / \mathrm{Ca}$ and $\mathrm{U} / \mathrm{Ca}$. The proportions of dissolved boron species, boric acid $\left(\mathrm{B}(\mathrm{OH})_{3}\right)$ and borate $\left(\mathrm{B}(\mathrm{OH})_{4}{ }^{-}\right)$, in seawater are governed by acid-base equilibria, whereby most boron exists in the form of $\mathrm{B}(\mathrm{OH})_{3}$ at low $\mathrm{pH}$, and $\mathrm{B}(\mathrm{OH})_{4}{ }^{-}$at high $\mathrm{pH}$ (Hershey et al., 1986). If only the charged $\mathrm{B}(\mathrm{OH})_{4}{ }^{-}$ion is thought to be included into foraminiferal calcite, as proposed by Hemming and Hanson, (1992), the B/Ca of foraminifer shells can be used to infer information about past ocean carbonate system chemistry. However, recent calcite precipitation experimental studies have shown the exclusive incorporation of $\mathrm{B}(\mathrm{OH})_{4}{ }^{-}$might not be the case (e.g., Uchikawa et al., 2015). Despite this, the $\mathrm{B} / \mathrm{Ca}$ ratio in foraminifer shells can be empirically related to the product of seawater the $\left[\mathrm{B}(\mathrm{OH})_{4}{ }^{-}\right] /\left[\mathrm{HCO}_{3}{ }^{-}\right]$ratio and the effective exchange coefficient (Yu et al., 2007):

$$
\mathrm{B} / \mathrm{Ca}=\mathrm{K}_{\mathrm{D}_{-} \mathrm{B} / \mathrm{Ca}}^{*} \cdot\left(\left[\mathrm{B}(\mathrm{OH})_{4}{ }^{-}\right] /\left[\mathrm{HCO}_{3}{ }^{-}\right]\right)
$$


where the square brackets indicate seawater concentrations, and $\mathrm{K}_{\mathrm{D} \_\mathrm{B} / \mathrm{Ca}}^{*}$ is the apparent (stoichiometric) exchange coefficient. Experimental culture studies confirm that the $\mathrm{B} / \mathrm{Ca}$ ratio in planktic foraminifer shells increases with seawater $\mathrm{pH}$ (Allen et al., 2011, 2012; Henehan et al., 2013), as high pH drives higher $\left[\mathrm{B}(\mathrm{OH})_{4}{ }^{-}\right]$and lower $\left[\mathrm{HCO}_{3}{ }^{-}\right]$in solution, increasing the $\left[\mathrm{B}(\mathrm{OH})_{4}{ }^{-} / \mathrm{HCO}_{3}{ }^{-}\right]$ratio. Thus, while the precise mechanisms behind $\mathrm{B}$ uptake into foraminifera are uncertain, we may relate $\mathrm{B} / \mathrm{Ca}$ in our cultured specimens to changes in microenvironment $\left[\mathrm{B}(\mathrm{OH})_{4}{ }^{-} / \mathrm{HCO}_{3}{ }^{-}\right]$and $\mathrm{pH}$.

The U/Ca composition of foraminiferal calcite is also sensitive to seawater carbonate chemistry, and shows a non-linear decrease with increasing $\left[\mathrm{CO}_{3}{ }^{2-}\right]$ in $\mathrm{pH}$ experiments (Russell et al., 2004). The incorporation of uranium into coral aragonite is suggested to occur as a uranyl carbonate complex, most likely the triscarbonato ion, $\left(\mathrm{UO}_{2}\left(\mathrm{CO}_{3}\right)_{3}{ }^{4-}\right)$, which is the dominant uranyl species over the range of modern seawater pH (see Djogić et al., 1986). The $\left[\mathrm{UO}_{2}\left(\mathrm{CO}_{3}\right)_{3}{ }^{4-}\right]$ ion likely requires a coordination change to fit into the calcite lattice (Reeder et al., 2000):

$$
\mathrm{CaCO}_{3(\mathrm{~s})}+\mathrm{UO}_{2}\left(\mathrm{CO}_{3}\right)_{3}{ }^{4-}{ }_{(\mathrm{qq})} \leftrightarrow \mathrm{UO}_{2} \mathrm{CO}_{3(\mathrm{~s})}+\mathrm{Ca}^{2+}{ }_{(\mathrm{aq})}+3 \mathrm{CO}_{3}{ }^{2-}{ }_{(\mathrm{aq})}
$$

This reaction has been used to describe the U/Ca composition of calcite as a function of the triscarbonate species and effective exchange coefficient (Russell et al., 2004):

$$
\mathrm{U} / \mathrm{Ca}=\mathrm{K}_{\text {D_U } / \mathrm{Ca}} \cdot\left[\mathrm{UO}_{2}\left(\mathrm{CO}_{3}\right)_{3}{ }^{4-}\right] /\left(\left[\mathrm{Ca}^{2+}\right] \cdot\left[\mathrm{CO}_{3}{ }^{2-}\right]^{3}\right)
$$

As the carbonate ion concentration and seawater $\mathrm{pH}$ increase, the cubic nature of the carbonate ion term in the partition coefficient denominator drives an exponential decrease in the sensitivity of U/Ca with carbonate ion activity in seawater.

To explore the response of shell trace element chemistry to seawater DIC and $\mathrm{pH}$, and the importance of physiologically controlled microenvironment effects, we conducted a small number of culture experiments on the symbiotic planktic foraminifer Orbulina universa. Orbulina universa is an ideal species for this purpose, as it calcifies continuously to produce 
100 a simple spherical shell comprising sequential diurnal growth bands (Eggins et al., 2004;

101 Spero et al, 2015). Here, we use a laser ablation-inductively coupled plasma-mass spectrometry (LA-ICP-MS) depth profiling technique (Eggins et al., 2004) to measure

103 banded variations in $\mathrm{Mg} / \mathrm{Ca}, \mathrm{B} / \mathrm{Ca}$ and $\mathrm{U} / \mathrm{Ca}$ through the shell. We interpret changes in the

104 magnitude and phase of banding in these elements in context of a physiological diffusion-

105 reaction model of the foraminifer-symbiont system, and estimate growth rates from the well-

106 established regular pacing of $\mathrm{Mg} / \mathrm{Ca}$ banding. The magnitude of $\mathrm{B} / \mathrm{Ca}$ and $\mathrm{U} / \mathrm{Ca}$ banding is

107 compared with the modelled diurnal variations in $\mathrm{pH},\left[\mathrm{B}(\mathrm{OH})_{4}{ }^{-} / \mathrm{HCO}_{3}{ }^{-}\right]$and $\left[\mathrm{CO}_{3}{ }^{2-}\right]$ at the

108 shell surface, combined with published sensitivities of the B/Ca and U/Ca proxies (Allen et

109 al., 2011; Russell et al., 2004) to determine whether microenvironment changes are sufficient

110 to drive $\mathrm{B} / \mathrm{C}$ and $\mathrm{U} / \mathrm{Ca}$ banding in O. universa (Fig. 2).

\section{METHODS}

\subsection{Foraminifer collection and culturing}

113 Orbulina universa were cultured using established methods (e.g., Russell et al., 2004)

114 during August 2013 at the Wrigley Institute for Environmental Studies (WIES), on Santa

115 Catalina Island, California. Small juvenile foraminifers were either hand collected by

116 SCUBA divers, or by plankton tow in the San Pedro Basin surface waters approximately $2 \mathrm{~km}$

117 NNE of WIES. Individual foraminifers were identified to species level and their largest

118 diameter was measured under an inverted microscope before being transferred into $120 \mathrm{~mL}$

119 soda-lime glass jars (Wheaton $\odot$ ). The jars were filled with experimental seawater and sealed

120 with a snap cap lid lined with Parafilm ${ }^{\mathrm{TM}} \mathrm{M}$ laboratory film to limit gas exchange with the

121 laboratory atmosphere. Foraminifers collected by plankton tow were transferred into

122 experimental seawater only after they had regrown their spines, and in two cases, this transfer

123 followed initial formation of their final spherical chamber. 
Culture jars containing foraminifers were placed in circulating water baths held at constant temperature, $21.92 \pm 0.13{ }^{\circ} \mathrm{C}$, monitored with HOBO TidbiT® loggers. A $12-12 \mathrm{hr}$ light-dark cycle was imposed for the duration of the culture experiments using Osram

127 Lumilux T5 skywhite high output bulbs to deliver a PAR irradiance level greater than or 128 equal to $285 \pm 23 \mu \mathrm{mol}$ photons $\mathrm{m}^{-2} \mathrm{~s}^{-1}$ ), to ensure light saturation of symbiont photosynthesis 129 (Rink et al., 1998). Light intensity was monitored every 7-10 days with a Biospherical Instruments QSP-2000 light meter. Foraminifers were fed a 1-day old brine shrimp (Artemia sp. nauplius, San Francisco Bay strain) every second day. Foraminifers typically underwent gametogenesis several days after forming their adult-stage spherical shell. Following gametogenesis, empty shells were rinsed in deionized water, air-dried and archived before being cleaned and analyzed at the ANU.

Seawater obtained from the foraminifer collection site was filtered $(0.8 \mu \mathrm{m})$ prior to use in experiments, and its $\mathrm{pH}$ and DIC adjusted to produce high and low DIC and high and low

$137 \mathrm{pH}$ compositions (Table 1). Artificial seawater with the observed salt composition of 138 seawater from Millero (1974) was made containing no DIC, and mixed with ambient 139 seawater to produce experimental seawater with low DIC concentration $\left(1026 \mu \mathrm{mol} \mathrm{kg}^{-1}\right)$. 140 Sodium bicarbonate was added to ambient seawater to produce experimental seawater with 141 double the ambient DIC concentration $\left(4019 \mu \mathrm{mol} \mathrm{kg}{ }^{-1}\right)$. Seawater $\mathrm{pH}$ was titrated with $0.1 \mathrm{M}$ $142 \mathrm{NaOH}$ or $0.1 \mathrm{M} \mathrm{HCl}$ to produce target $\mathrm{pH}$ values of $7.53,7.96 / 7.97$ and 8.44 (total scale).

143 Uranium and boron were enriched in experimental seawaters to facilitate subsequent 144 microanalysis of $\mathrm{B} / \mathrm{Ca}$ and $\mathrm{U} / \mathrm{Ca}$ in foraminifer shells. Enrichment was achieved by addition 145 of a uranium chloride and boric acid stock solutions, to levels of 50x ambient seawater U and $1465 x$ ambient seawater B concentration, except for the low DIC seawater which was enriched to 147 just below half this level. 
The total alkalinity of experimental seawater was measured by Gran-titration using a

149 Metrohm 809 open cell autotitrator that was standardized using Dickson certified reference

150 seawater. Seawater $\mathrm{pH}$ was measured with a Metrohm $\mathrm{pH}$ electrode that had been calibrated

151 to the NBS scale using low ionic strength $\mathrm{pH}$ buffers ( $\mathrm{pH} 4.00,7.00$ and 10.00; Fisherbrand).

152 The $\mathrm{pH}$ and alkalinity of experimental seawaters were measured at the beginning and end of

153 all experiments to monitor the consistency of carbonate system chemistry during

154 experiments. Calculation of the carbonate system equilibria, and conversion from $\mathrm{pH}_{\mathrm{NBS}}$ to

155 the $\mathrm{pH}_{\text {TOTAL }}$ scale, were performed using a modified version of the van Heuven et al. (2011)

156 Matlab script (CO2SYS.m) that accommodates changes to seawater $[B]_{\mathrm{T}}$ independent of

157 salinity. Uranium speciation was calculated from $[\mathrm{U}]_{\mathrm{T}}$ using aqueous thermodynamic data

158 from Djogić et al. (1986). Small samples of experimental seawater were filtered using 0.22

$159 \mu \mathrm{m}$ Millipore syringe filters, transferred to acid cleaned $15 \mathrm{~mL}$ plastic vials and acidified to

$160 \mathrm{pH} \sim 4$ with optima grade $\mathrm{HNO}_{3}$ for later trace element analysis at the ANU.

\section{2.2. Sample Preparation and Analysis}

162 Seawater trace metal concentrations were measured using a Varian Vista Pro Axial ICP-

163 AES and a Varian 820 Quadrupole ICP-MS at the Research School of Earth Sciences, the

164 Australian National University (RSES, ANU; Supplementary material, Table S1). Seawater samples were diluted $10 \mathrm{x}$ with $2 \% \mathrm{HNO}_{3}$ for analysis by ICP-AES using a three-point external calibration curve, run at the beginning and end of each analytical session, and a

167 standard-sample-standard bracketing protocol to correct for instrument drift. Seawater B/Ca,

$168 \mathrm{Mg} / \mathrm{Ca}$, and $\mathrm{Sr} / \mathrm{Ca}$ molar ratios were measured with a reproducibility of $\pm 1.25 \%, \pm 0.13 \%$,

169 and $\pm 0.16 \%(1 \sigma)$ based on repeated analysis of the CASS-4 seawater reference material

170 (NRC, Canada). We also measured seawater by ICP-MS to measure Mn/Ca and U/Ca, which

171 were below or near the detection limits of ICP-AES, and to validate $\mathrm{B} / \mathrm{Ca}, \mathrm{Mg} / \mathrm{Ca}$ and $\mathrm{Sr} / \mathrm{Ca}$ measurements. For ICP-MS analysis seawater samples were diluted $100 \mathrm{x}$ with $2 \% \mathrm{HNO}_{3}$. 
173 Instrument drift was monitored and corrected using a combination of internal standards $\left({ }^{9} \mathrm{Be}\right.$,

$174{ }^{45} \mathrm{Sc},{ }^{89} \mathrm{Y},{ }^{115} \mathrm{In}$, and ${ }^{235} \mathrm{U}$ ) and measurement of a synthetic seawater standard every five 175 samples. Seawater B/Ca, $\mathrm{Mg} / \mathrm{Ca}, \mathrm{Mn} / \mathrm{Ca}, \mathrm{Sr} / \mathrm{Ca}$, and $\mathrm{U} / \mathrm{Ca}$ molar ratios were measured with a 176 precision of $\pm 0.9 \%, \pm 1.3 \%, \pm 1.5 \%, \pm 1.0 \%$, and $\pm 2.1 \%(1 \sigma)$ respectively, based on repeat analyses of CASS-4 seawater. Accuracy relative to average seawater ratios for $\mathrm{B} / \mathrm{Ca}, \mathrm{Mg} / \mathrm{Ca}$, $\mathrm{Sr} / \mathrm{Ca}$ and $\mathrm{U} / \mathrm{Ca}$ is $1.0 \%, 1.5 \%, 3.7 \%$ and $14 \%$ and $\mathrm{Mn} / \mathrm{Ca}$ relative to CASS-4 is $1.9 \%$. LA-ICP-MS analysis by cracking shells open with a scalpel blade, followed by immersion in 181 a 50:50 solution of $30 \%$ hydrogen peroxide and $0.1 \mathrm{M} \mathrm{NaOH}$ in a water bath at $55 \pm 5{ }^{\circ} \mathrm{C}$ for $182 \sim 10$ minutes (Pak et al., 2004). The buffered solution was then removed and the shell repeatedly rinsed with ultra-pure milli-Q water before being mounted on carbon tape for analysis (Eggins et al., 2003, 2004). Trace element/Ca (TE/Ca) ratios were measured using a Varian 820 Quadrupole ICP-MS coupled to an ArF excimer laser $(\lambda=193 \mathrm{~nm}$, pulse width $=$ 25 ns FWHM) via an ANU Helex laser ablation system at the RSES, ANU following Eggins et al. (2003, 2004; Supplementary material, Table S2). Laser ablation sampling was conducted using $70 \mu \mathrm{m}$ diameter circular spots at a laser pulse rate of $3 \mathrm{~Hz}$ at a fluence of $\sim 2$ $\mathrm{J} / \mathrm{cm}^{2}$. A mixed He-Ar gas stream was used to transfer ablation products to the ICP-MS. A rapid peak hopping protocol, employing 10 to $30 \mathrm{~ms}$ dwell times per isotope depending on abundance, was applied to measure selected analyte isotopes $\left({ }^{10} \mathrm{~B},{ }^{11} \mathrm{~B},{ }^{24} \mathrm{Mg},{ }^{25} \mathrm{Mg},{ }^{27} \mathrm{Al}\right.$, ${ }^{43} \mathrm{Ca},{ }^{44} \mathrm{Ca},{ }^{55} \mathrm{Mn},{ }^{87} \mathrm{Sr},{ }^{88} \mathrm{Sr}$, and $\left.{ }^{238} \mathrm{U}\right)$ repeatedly every $\sim 0.35$ seconds for a duration of $30-90$ seconds, depending on shell thickness. Three profiles were measured from inside to outside through each foraminifer shell.

The ICP-MS instrument response was calibrated using SRM NIST610 glass and corrected for variation in ablation yield and instrument drift by normalizing to the measured

197 internal standard isotope $\left({ }^{43} \mathrm{Ca}\right.$ and $\left.{ }^{44} \mathrm{Ca}\right)$ intensities during each mass spectrometer cycle. An 
198 in-house carbonate standard was measured periodically to monitor the consistency of 199 carbonate ablation relative to the SRM NIST 610. LA-ICP-MS data reduction followed well

200 established procedures for time-resolved analysis (Longerich et al., 1996), including the 201 initial screening of mass-time spectra for outliers and subtracting mean background 202 intensities (measured with laser off). The mean TE/Ca ratio obtained from each 203 compositional profile was averaged to produce a bulk shell composition for each specimen. 204 Multiple profiles obtained from each foraminifer shell were combined to produce an average 205 profile by identifying and aligning common peaks using the Linage function in AnalySeries 206 v1.2, following Allen et al. (2011). To isolate only the banding patterns in our data, a 207 Butterworth bandpass Fourier filter (Butterworth, 1930) was applied to the LA-ICP-MS 208 profiles to remove low frequency (period $>5 \mu \mathrm{m}$ ) trends and high frequency (period $<0.5$ $209 \mu \mathrm{m})$ noise using the scipy.signal python package (Jones et al., 2001). The long period 210 patterns are the gradually increasing trends of $\mathrm{Mg} / \mathrm{Ca}, \mathrm{B} / \mathrm{Ca}$ and $\mathrm{U} / \mathrm{Ca}$ that occur through the 211 test from the inside of the POS to the outside of the shell, and short period patterns are 212 instrumental noise.

213 The time taken to measure each shell compositional profile was converted to shell wall 214 thickness and depth relative to the internal shell surface, assuming each laser pulse removed a $2150.1 \mu \mathrm{m}$ thick layer of calcite (Eggins et al., 2003). Linear calcification rate can then be 216 converted to rate with units of mass per unit surface area per unit time using the density of 217 calcite. 
The diurnal phasing of the variation shown by different trace elements is determined by comparison to the diurnal pattern of $\mathrm{Mg} / \mathrm{Ca}$ banding (Fig. 3), which is characterized by high Mg bands formed at night and low Mg bands during the day (Spero et al., 2015). Measured trace element/Ca ratio profiles through the final spherical chamber wall of $O$. universa shells all show significant compositional growth banding (Fig. 3-Fig. 5). In most cases, the diurnal $\mathrm{Mg} / \mathrm{Ca}$ banding is accompanied by a trend of increasing $\mathrm{Mg} / \mathrm{Ca}$ away from the primary organic sheet (POS) towards the outside of the shell (see Fig. 3).

The POS is located in a band of relatively low $\mathrm{Mg} / \mathrm{Ca}$ near the inner shell surface and in some cases associated with an anomalous high U/Ca band (Eggins et al., 2004; Sadekov et al., 2005). The number of low and high $\mathrm{Mg} / \mathrm{Ca}$ band pairs developed between the POS and external surface is consistent with the number of days each foraminifer lived in experimental culture after formation of its final spherical chamber, as recorded in daily culture logs.

Profiles of $\mathrm{Mg} / \mathrm{Ca}, \mathrm{B} / \mathrm{Ca}$ and $\mathrm{U} / \mathrm{Ca}$ with the associated noise and background trends removed with a Butterworth bandpass filter are plotted in Fig. 4. B/Ca banding is generally out of phase with $\mathrm{Mg} / \mathrm{Ca}$, and where present $\mathrm{U} / \mathrm{Ca}$ banding is broadly in phase with $\mathrm{Mg} / \mathrm{Ca}$ in most shells (Fig. 4). Given the diurnal nature of $\mathrm{Mg} / \mathrm{Ca}$ (Spero et al., 2015), this suggests that high $\mathrm{B} / \mathrm{Ca}$ bands precipitate during the day and low $\mathrm{B} / \mathrm{Ca}$ bands precipitate during the night, and the converse applies to U/Ca. While the number of specimens considered here is small, we observe that $\mathrm{B} / \mathrm{Ca}$ and $\mathrm{U} / \mathrm{Ca}$ banding are most clearly developed in the low $\mathrm{pH}$ and low DIC experiments (Fig. 4 a-d). U/Ca banding in the high DIC experiments is less well 241 developed and possibly absent (Fig. 4 e-f).

$\mathrm{Mn} / \mathrm{Ca}$ banding is notable for occurring in shells grown in low DIC seawater, but is not obvious in other experiments (Fig. 5). Sr/Ca shows no evidence of diurnal banding, although significant variations do occur in many shells. In particular, $\mathrm{Sr} / \mathrm{Ca}$ ratios tend to be lower 
between the POS and inner shell surface (Fig. 5). Other notable features are the presence of relatively high $\mathrm{Mn} / \mathrm{Ca}$ and $\mathrm{Mg} / \mathrm{Ca}$ ratios at the inner shell surface (Fig. 5).

\subsection{TE/Ca variations with carbonate system variables}

The mean bulk shell compositions of each experimental group (Fig. 6) are calculated using the average profile compositions of each shell, excluding the contribution of calcite precipitated prior to the experiment. Our bulk shell composition estimates have significant uncertainties, due to the small number of shells analyzed in each experiment and the variable compositions between individual shells. Accordingly, we caution against using the results reported here for the purpose of proxy calibration and reconstruction of seawater carbonate system parameters.

Bulk shell $\mathrm{Mg} / \mathrm{Ca}$ and $\mathrm{Sr} / \mathrm{Ca}$ compositions correlate with DIC, with the increase in $\mathrm{Sr} / \mathrm{Ca}$ from $1.19 \pm 0.07$ to $1.71 \pm 0.02 \mathrm{mmol} / \mathrm{mol}$ being highly significant (Pearson $\mathrm{R}$ correlations:

$\mathrm{Sr} / \mathrm{Ca}-\mathrm{DIC}, \mathrm{R}=0.98, p=0.02, n=4 ; \mathrm{Mg} / \mathrm{Ca}-\mathrm{DIC}, \mathrm{R}=0.99, p<0.01, n=4)$.

The $\mathrm{B} / \mathrm{Ca}$ of shells measured in this study is high compared to natural specimens because of the elevated $[\mathrm{B}]_{\mathrm{T}}$ in our experimental seawaters. To compare data between our experiments, the $\mathrm{B} / \mathrm{Ca}$ of the low DIC specimens must be corrected for the two-fold lower $[\mathrm{B}]_{\mathrm{T}}$ than other treatments. This correction is made using the $\mathrm{B} / \mathrm{Ca}-\left[\mathrm{B}(\mathrm{OH})_{4}{ }^{-}\right]$relation of

Allen et al. (2011) for O. universa $\left(\mathrm{B} / \mathrm{Ca}=1.4^{*}\left[\mathrm{~B}(\mathrm{OH})_{4}{ }^{-}\right]-39.5\right)$. After correction, bulk $\mathrm{B} / \mathrm{Ca}$ has a positive trend with seawater $\left[\mathrm{CO}_{3}{ }^{2-}\right](\mathrm{R}=0.74)$ and a positive trend with seawater $\mathrm{pH}(\mathrm{R}=0.90)$, although the correlations are not significant at the $95 \%$ confidence level $(p=$ 0.26 and 0.09 , respectively).

Measured shell U/Ca values in the low DIC experiment are corrected for the $3.1 \mathrm{x}$ lower seawater $[\mathrm{U}]_{\mathrm{T}}$ in this experiment, assuming a linear relationship between shell U/Ca and 
270 form a negative non-linear trend with $\left[\mathrm{CO}_{3}{ }^{2-}\right](\mathrm{R}=0.86, p=0.14, n=4)$, although the 271 correlation is not significant.

272 Shell $\mathrm{Mn} / \mathrm{Ca}$ values are low $(<1 \mu \mathrm{mol} / \mathrm{mol})$, except in the low DIC experiment, which 273 had 4.7x higher $[\mathrm{Mn}]_{\mathrm{T}}$ than the other experiments (Fig. 5 a-b). The measured shell $\mathrm{Mn} / \mathrm{Ca}$ in 274 this experiment was linearly corrected to a $4.7 \mathrm{x}$ lower $\mathrm{Mn} / \mathrm{Ca}$ value assuming partitioning 275 scales with $[\mathrm{Mn}]_{\mathrm{T}}$ concentration (Eggins, unpublished data). Strong negative relationships are observed between $\mathrm{Mn} / \mathrm{Ca}$ and both DIC (Mn/Ca $-\mathrm{DIC}, \mathrm{R}=-0.96, p=0.04, n=4)$.

\subsection{Partition coefficient changes with calcification rate}

Mean linear growth rates are determined by dividing the shell wall thickness (profile length) by the observed number of diurnal growth band pairs (each of which reflects $24 \mathrm{hrs}$ of growth). These rate estimates increase in experimental order from low DIC $<$ low $\mathrm{pH}<$ high $\mathrm{pH}<$ high DIC (Supplementary material, Table S2), but are notable for falling in a narrow range between $0.14 \pm 0.02$ and $0.28 \pm 0.02 \mu \mathrm{m} \mathrm{hr}^{-1}$, despite the large range of saturation state

$(\Omega)$ across these experiments. Our linear calcification rates measured for $O$. universa correspond to values of $\mathrm{R}\left(\log _{10}\right.$ Rate $\left.\mathrm{mol} \mathrm{m} \mathrm{m}^{2} \mathrm{~s}^{-1}\right)=-6.5$ and -6.1 . Although the calcification rate uncertainties are large due to the small number of individuals grown in each experiment, a general increase in calcification rate with increasing calcite saturation state is apparent. dividing the respective shell $\mathrm{TE} / \mathrm{Ca}$ by seawater $\mathrm{TE} / \mathrm{Ca}$ ratios. Because $\mathrm{B}$ and $\mathrm{U}$ do not

290 substitute for $\mathrm{Ca}^{2+}$, shell $\mathrm{B} / \mathrm{Ca}$ and $\mathrm{U} / \mathrm{Ca}$ are divided by $\left(\left[\mathrm{B}(\mathrm{OH})_{4}{ }^{-}\right] /\left[\mathrm{HCO}_{3}{ }^{-}\right]\right)$and $291\left[\mathrm{UO}_{2}\left(\mathrm{CO}_{3}\right)_{3}{ }^{4-}\right] /\left(\left[\mathrm{Ca}^{2+}\right] \cdot\left[\mathrm{CO}_{3}{ }^{2-}\right]^{3}\right) ;$ Equations 1 and 3), from carbon and boron species concentrations calculated in CO2SYS, and for uranium species concentrations calculated

293 from Djogić et al. (1986) for each experimental condition. There are significant increases in $294 \mathrm{~K}_{\mathrm{D}_{-} \mathrm{Mg} / \mathrm{Ca}}$ and $\mathrm{K}_{\mathrm{D} \_\mathrm{Sr} / \mathrm{Ca}}$ with calcification rate (Fig. 7; $\mathrm{R}=0.95,0.95$, and $p=0.05,0.05$, 
respectively, $n=4$ ), and a significant decrease in $\mathrm{K}_{\mathrm{D} \_\mathrm{Mn} / \mathrm{Ca}}$, with calcification rate (Fig. 7; $\mathrm{R}=$ -0.99 , and $p<0.01, n=4)$. No consistent relationship is observed for either $\mathrm{K}_{\mathrm{D}_{-} \mathrm{B} / \mathrm{Ca}}$ or $\mathrm{K}_{\mathrm{D}_{-} \mathrm{U} / \mathrm{Ca}}$ with growth rate.

\section{DISCUSSION}

$300 \quad 4.1 \quad$ Intra-shell composition response to microenvironmental carbonate system variations

The $\mathrm{B} / \mathrm{Ca}$ and $\mathrm{U} / \mathrm{Ca}$ compositional banding we document in $O$. universa shells is qualitatively consistent with the expected variation of these geochemical proxies due to diurnal changes in the effects of net photosynthesis-respiration on $\mathrm{pH},\left[\mathrm{B}(\mathrm{OH})_{4}{ }^{-} / \mathrm{HCO}_{3}{ }^{-}\right]$and $\left[\mathrm{CO}_{3}{ }^{2-}\right]$ within the microenvironment of O. universa (Fig. 2). The spatial coherence of high $\mathrm{B} / \mathrm{Ca}$ bands with low $\mathrm{Mg} / \mathrm{Ca}$ bands that are formed during the day (Spero et al., 2015) (Fig. 4), is consistent with the daytime photosynthetic drawdown of $\mathrm{CO}_{2}$ and resulting elevation of $\mathrm{pH}$ and $\left[\mathrm{B}(\mathrm{OH})_{4}{ }^{-} / \mathrm{HCO}_{3}{ }^{-}\right]$in the microenvironment of $O$. universa. Similarly, the synchronicity of high $\mathrm{U} / \mathrm{Ca}$ bands with high $\mathrm{Mg} / \mathrm{Ca}$ bands that are formed during the night, is consistent with an increase in net respired $\mathrm{CO}_{2}$ at night and resulting decrease in

310 microenvironmental $\mathrm{pH}$ and $\left[\mathrm{CO}_{3}{ }^{2-}\right]$. The phasing of high $\mathrm{U} / \mathrm{Ca}$ bands with high $\mathrm{Mg} / \mathrm{Ca}$ bands are clearest in the low DIC and low pH experiments (Fig. 4 a-d). This is consistent with the enhanced sensitivity of $\mathrm{U} / \mathrm{Ca}$ at the lower concentrations of $\left[\mathrm{CO}_{3}{ }^{2-}\right]$ of these experiments, described by both theory (Equation 3) and the empirical bulk shell calibration of Russell et al.

314 (2004). Conversely, the absence of strong U/Ca banding in specimens grown in high DIC and high $\mathrm{pH}$ experiments is likely the result of the lower sensitivity of $\mathrm{U} / \mathrm{Ca}$ to $\left[\mathrm{CO}_{3}{ }^{2-}\right]$ at high concentrations of $\left[\mathrm{CO}_{3}{ }^{2-}\right]$ (Russell et al., 2004) driving any $\mathrm{U} / \mathrm{Ca}$ variations below our analytical precision.

In an effort to quantify the extent of the microenvironmental influence on shell chemistry, we combine the proxy calibrations of Allen et al. (2011) and Russell et al. (2004) 
with the diffusion-reaction model developed by Zeebe et al. (2003) to predict compositional changes in shell $\mathrm{B} / \mathrm{Ca}$ and $\mathrm{U} / \mathrm{Ca}$ arising from the carbonate chemistry variation over diurnal cycles. The diffusion-reaction model was run for both light and dark conditions, using the results for the different seawater chemistries of each experiment as a basis for comparing observed and predicted shell compositions and diurnal variation. The model calculates concentration profiles of the carbonate system parameters in the chemical microenvironment of the foraminifer using fixed rates of photosynthesis, respiration and calcification of respectively 10, 2 and $3 \mathrm{nmol} \mathrm{C} \mathrm{h}{ }^{-1}$ in the light, and 0,2 and $1 \mathrm{nmol} \mathrm{C} \mathrm{h}^{-1}$ in the dark (Lea et al., 1995; Rink et al., 1998; Zeebe et al., 2003). The carbonate chemistry calculated at the shell surface in the dark (night) and the light (day) is then used to estimate the diurnal changes in $\mathrm{B} / \mathrm{Ca}$ and $\mathrm{U} / \mathrm{Ca}$ compositions based on published sensitivities to seawater carbonate chemistry. The de-trended profiles are plotted against the calculated diurnal composition changes in Fig. 8.

The amplitude of observed B/Ca banding between the POS and outer surfaces of shells generally matches the predicted compositional variation. However, the measured U/Ca variation is generally much greater than the predicted amplitude of U/Ca banding (Fig. 8 b, d, $\mathrm{f}, \mathrm{h})$. Possible explanations for this could be a greater $\mathrm{U} / \mathrm{Ca}-\left[\mathrm{CO}_{3}{ }^{2-}\right]$ sensitivity than previously reported by bulk calibrations (equal to or greater than 3 times) or differences in the relative carbon fluxes used in the model of Zeebe et al. (2003) to describe foraminiferal physiology. Differences in the strength of photosynthesis and calcification might explain

340 some of the differences in banding within and between individuals (e.g., Fig. 8 i - j).

341 However, varying calcification, photosynthesis and respiration carbon fluxes in the model over a range that exceeds the observed carbon flux values cannot explain the variation

343 measured in both $\mathrm{B} / \mathrm{Ca}$ and $\mathrm{U} / \mathrm{Ca}$ bands (Fig. $8 \mathrm{i}-\mathrm{j}$ ). This suggests that disparities from 344 modelled bands could be the result of limitations associated with bulk calibrations. This may 
345 be explained by the fact that, bulk shell calibrations integrate day and night calcite, thereby 346 varying the individual contributions of light-dependent physiological processes on the 347 internal carbonate system of the foraminifer. Disparities from predictions could also arise 348 from internal biomineralization processes that influence $\mathrm{U} / \mathrm{Ca}$ and $\mathrm{B} / \mathrm{Ca}$ differently. For 349 example, if foraminifers employ either carbon concentrating or proton pumping mechanisms, 350 the associated changes to either DIC and/or $\mathrm{pH}$ will affect $\mathrm{U}$ and B incorporation differently, through their individual sensitivities to DIC and $\mathrm{pH}$.

The diffusion-reaction model results are influenced by how far the symbiont swarm extends from the surface of the shell. As noted in our culture logs, in culture experiments, the density and position of the symbiont halo can vary greatly between individual foraminifers and throughout their ontogeny. This could also vary systematically with different experimental conditions as the symbionts might adjust their position subject to both light and carbon availability. Despite these caveats, the model demonstrates that the geochemical banding observed within $O$. universa shells is broadly consistent with diurnal changes in microenvironment carbonate chemistry produced by photosynthesis, respiration and 360 calcification.

This is the first study to evaluate $\mathrm{B} / \mathrm{Ca}$ and $\mathrm{U} / \mathrm{Ca}$ banding in symbiotic planktic foraminifers, and extends the observations on O. universa reported by Allen et al. (2011).

363 Comparable B data have been reported by Branson et al. (2015) who, using a high-resolution 364 scanning transmission $\mathrm{x}$-ray microscope, observe $\mathrm{B}$ bands that peak just after $\mathrm{Mg}$ bands in the 365 benthic foraminifer Amphistegina lessonii. Although this appears to conflict with our result, it 366 is important to note that this species belongs to a different suborder than $O$. universa, and that $\mathrm{Mg} / \mathrm{Ca}$ banding in $A$. lessonii has been linked to chamber addition rather than having a diurnal origin (Bentov and Erez, 2005; Erez, 2003). The phasing of $\mathrm{B} / \mathrm{Ca}$ and $\mathrm{Mg} / \mathrm{Ca}$ banding 
in this species is therefore likely to be driven by a distinct mechanism rather than the diurnal

370

371

372

373

374

375

376

377

378

379

380

381

382

383

384

385

386

387 processes active in $O$. universa.

In contrast to good agreement between modeled and observed $\mathrm{B} / \mathrm{Ca}$ in foraminifer shells outside the POS, predicted B/Ca does not match what was observed between the POS and the inner shell surfaces (see Fig. 8 a, c, e, g). Anomalous high U/Ca values at the position of the POS are a prominent feature in many shells, particularly in the low $\mathrm{pH}$ and high DIC experiments (Fig. 3 c-d, e-f). The origin of these elevated U/Ca bands is unclear, and might reflect initial calcification of the spherical adult chamber of $O$. universa at significantly lower $\left[\mathrm{CO}_{3}{ }^{2-}\right]$ than during subsequent shell calcification. Alternatively, high uranium contents associated with the POS might be a product of uranium adsorption or accumulation at this organic layer, in a similar manner to the sequestration of uranium carbonate complexes onto cell surfaces and associated components in marine cyanobacteria (Acharya et al., 2009). This feature might also be at the limit of LA-ICP-MS depth resolution, and therefore is not fully resolved in all shells.

Several assumptions underpin our ability to predict diurnal changes in shell compositions using the diffusion-reaction model. Firstly, the empirical proxy relationships we apply to our data have been calibrated using bulk shell compositions and over a range of seawater compositions that are much narrower than our DIC experiments. Secondly, the rates of photosynthesis and respiration are constant in the model, although they have been observed to change daily with changes in symbiont productivity (Spero and Parker, 1985) and throughout the foraminifer's ontogeny as it grows and symbiont numbers increase (Fujiki et al. 2014; Spero and Parker, 1985; Takagi et al., 2016). This might explain why B/Ca and U/Ca banding overlies broader compositional trends that occur with shell thickening over multiple days of growth (Fig. 3). 
The bulk $\mathrm{B} / \mathrm{Ca}$ and $\mathrm{U} / \mathrm{Ca}$ systematics observed here are qualitatively consistent with

(Fig. 6). Shell B/Ca compositions show a positive correlation with $\left[\mathrm{B}(\mathrm{OH})_{4}{ }^{-} / \mathrm{HCO}_{3}{ }^{-}\right]$as expected based on equation 1, albeit with a significant positive intercept (Fig. 9). The trend and intercept are broadly consistent with results from previous studies, after taking into account the $[\mathrm{B}]_{\mathrm{T}}$ difference between studies.

The lack of a $\mathrm{Mg} / \mathrm{Ca}-\mathrm{pH}$ relationship is notable, given previously reported $7 \pm 5 \%$ $\mathrm{Mg} / \mathrm{Ca}$ sensitivity to $\mathrm{pH}$ (Russell et al, 2004). The absence of this relationship may be attributable to the high variability of $\mathrm{Mg} / \mathrm{Ca}$ between individual shells (Sadekov et al., 2008; Spero et al., 2015), combined with the limited specimen numbers in our study. The variability of TE/Ca ratios between individuals could be due to a range of factors, for example, organism size, growth rate and genetic factors (Boyle, 1995), as well as the size, growth rate and location of the symbiont population.

\subsection{Calcification rate effects on trace element incorporation}

410 The twofold increase of foraminifer calcification rate over the large experimental range

411 of DIC and $\Omega$ is significantly lower than the precipitation rate increase predicted for

412 inorganic calcite. Using calcite precipitation rate calculations of Butron and Walter (1987),

413 increasing solution saturation state from 2 to 8 results in an increase of inorganic precipitation

414 rate by 20 times, this is an order of magnitude larger than for $O$. universa. The twofold 415 increase in calcification rate from the low DIC to high DIC experiments (low to high $\left[\mathrm{CO}_{3}{ }^{2-}\right]$ ) 416 is broadly consistent with a twofold increase in shell thickness over a ten-fold increase of $417\left[\mathrm{CO}_{3}^{-2}\right]$ observed Bijma et al. (1999) and Russell et al. (2004), who attributed this observation 418 to increased shell calcification rates. Our $\log _{10}$ Rate values are consistent with previous rate 
419 estimates for other planktic foraminifers (i.e. $\mathrm{R}=-6.6$ to -6.0 ) grown over a similar range of 420 seawater $\Omega$ (see Fantle and Tipper, 2014, and calculated using calcium isotope data from 421 Gussone et al., 2003 and Kisakürek et al., 2011).

422 A wealth of experimental data and an extensive theoretical basis underpin evidence for 423 the effect of calcification rate on trace element incorporation into calcite (see DePaolo, 2011; 424 Gabitov and Watson, 2006; Lorens, 1981; Nielsen et al., 2012; Tesoriero and Pankow, 1996). In general, in inorganic calcite, $\mathrm{Sr}$ and other incompatible trace elements $\left(\mathrm{K}_{\mathrm{D}}<1\right)$ exhibit larger partition coefficients with increasing calcite precipitation rate, whereas $\mathrm{Mn}$ and other compatible trace elements $\left(K_{D}>1\right)$ experience smaller partition coefficients with increased precipitation rate (Dromgoule \& Walter, 1990; Lorens, 1981; Tang et al., 2008; Tesoriero \& Pankow, 1996). At faster precipitation rates trace element behaviour tends toward kinetic fractionation, whereas at slower precipitation rates equilibrium partitioning dominates (DePaolo, 2011). The apparent sensitivity of bulk shell $\mathrm{Mg} / \mathrm{Ca}, \mathrm{Sr} / \mathrm{Ca}$ and $\mathrm{Mn} / \mathrm{Ca}$ compositions to seawater carbonate system parameters could reflect the effect of these parameters on calcification rate, with $\mathrm{Sr} / \mathrm{Ca}$ and $\mathrm{Mg} / \mathrm{Ca}$ increasing and $\mathrm{Mn} / \mathrm{Ca}$ decreasing with increasing calcification rate (and $\Omega$ ). These results lend support to the previous suggestion of increasing $\mathrm{Sr} / \mathrm{Ca}$ ratios in planktic foraminifers with increasing calcification rate (Dueñas-Bohórquez et al., 2009; Kisakürek et al., 2008; Lea et al., 1999). Variation in calcification rates might also contribute to observed compositional differences between 438 calcite precipitated on either side of the POS in individual shells. Very thin diurnal $\mathrm{Mg} / \mathrm{Ca}$ 439 bands on the inside of the POS indicate calcification proceeds about 5 times slower at the 440 inner shell surface than the outer surface in $O$. universa (Spero et al., 2015). These slower 441 calcification rates might explain the higher $\mathrm{Mn} / \mathrm{Ca}$ compositions and tendency toward lower $442 \mathrm{Sr} / \mathrm{Ca}$ compositions between the inner surface and the primary organic sheet (see Figs. 5 and 443 7). Whether differences in day and night calcification rates might also be sufficient to 
444 modulate the amplitude of diurnal banding remains to be established. This will require future

445 use of higher resolution analysis methods to constrain day and night calcification rates.

446 Calcification rates slower than $\mathrm{R}=-6.0$ are within the range where kinetic effects

447 influence Sr and Mn partitioning into calcite (DePaolo, 2011; Lorens, 1981; Tang et al.,

448 2008; Tesoriero and Pankow, 1996). However, they fall below the rates where kinetic effects

449 have been shown to strongly influence inorganic B partitioning into calcite (i.e. $\mathrm{R}>-6$,

450 Uchikawa et al., 2015). The narrow range of shell calcification rates exhibited by $O$. universa

451 further suggests that calcification rate is unlikely to exert a large influence on bulk shell $\mathrm{B} / \mathrm{Ca}$

452 compositions. We suggest that both $\mathrm{B} / \mathrm{Ca}$ and $\mathrm{U} / \mathrm{Ca}$ are much more sensitive to ambient

453 seawater carbonate chemistry at the intra-shell scale than rate, given that $O$. universa and

454 other planktic foraminifers appear to regulate their shell calcification rates within narrow 455 limits.

\section{CONCLUSIONS}

It is important to understand how and why trace elements vary within foraminifer shells, in order to constrain "vital effects" on trace element to calcium ratio proxies recorded in foraminiferal calcite. In O. universa the $\mathrm{B} / \mathrm{Ca}$ compositional banding is out-of-phase with

460 diurnal $\mathrm{Mg} / \mathrm{Ca}$ banding, and $\mathrm{U} / \mathrm{Ca}$ banding, where present, is in-phase with $\mathrm{Mg} / \mathrm{Ca}$ banding.

$461 \mathrm{~B} / \mathrm{Ca}$ banding and in many cases $\mathrm{U} / \mathrm{Ca}$ banding are qualitatively consistent with the respective proxy responses to diurnal changes in the carbonate system chemistry within the chemical microenvironment of the foraminifer, based on $\mathrm{B} / \mathrm{Ca}$ and $\mathrm{U} / \mathrm{Ca}$ relationships established using bulk analytical methods. These carbonate system changes result from the

465 net effects of respiration, calcification, and the photosynthetic activity of symbionts. 466 However, there is a greater variation of $\mathrm{U} / \mathrm{Ca}$, and of $\mathrm{B} / \mathrm{Ca}$ (in the high and low DIC 467 experiments), within individual shells than predicted by microenvironment modelling. It is 
not clear whether this is due to limitations with the sensitivities of the bulk shell proxy calibrations used, to the sizes of the net carbon fluxes attributed to photosynthesis and respiration in the modeled microenvironment, or additional factors that are specific to the biomineralization process. Thus, our current understanding of diurnal microenvironmental variability is sufficient to explain the relative phasing, but not amplitude of $\mathrm{Mg} / \mathrm{Ca}, \mathrm{B} / \mathrm{Ca}$ and 473 U/Ca banding.

A quadrupling of DIC and calcite saturation state of seawater only results in a doubling of shell calcification rates. The small number of foraminifers cultured and analysed in this study reveal that DIC concentration and calcification rate have positive correlations with bulk shell $\mathrm{Sr}$ and $\mathrm{Mg}$ partitioning, and a negative correlation with bulk Mn partitioning. No significant calcification rate effect is observed for bulk shell $\mathrm{B}$ and $\mathrm{U}$ partitioning. This may be a consequence of the small (factor of two) range in calcification rate, and greater sensitivity of these elements to seawater $\mathrm{pH}$ and DIC.

\section{ACKNOWLEDGEMENTS}

We thank Richard Zeebe for providing his diffusion-reaction model code, and Les Kinsley and Linda McMorrow for supporting chemical analysis of foraminifer shells and seawaters at the RSES, ANU. We are grateful to the staff at USC Wrigley Institute for 486 Environmental Studies, and the industrious efforts of Ann Russell, Jennifer Fehrenbacher, Jordan Snyder, Kate Davis, Caroline Baptist, Alex Gagnon and Elisa Bonnin throughout the field season at WIES on Catalina Island; this work would not have been possible without their support. This manuscript benefitted from thoughtful comments from two anonymous reviewers. This research was supported by ARC Discovery grants DP0880010 and DP11001378 to SE and NSF grant OCE 12-32987 to BH. 
494

495

496

497

498

499

500

501

502

503

504

505

506

507

508

509

510

511

512

513

514

515

516

517

518

519

520

521

522

523

524

525

526

527

528

529

530

531

532

533

534

535

536

Acharya, C., Joseph, D., \& Apte, S. K. (2009). Uranium sequestration by a marine cyanobacterium, Synechococcus elongatus strain BDU/75042. Bioresource Technology, 100(7), 2176-2181. doi: http://dx.doi.org/10.1016/j.biortech.2008.10.047

Allen, K. A., Hönisch, B., Eggins, S. M., \& Rosenthal, Y. (2012). Environmental controls on $\mathrm{B} / \mathrm{Ca}$ in calcite tests of the tropical planktic foraminifer species Globigerinoides ruber and Globigerinoides sacculifer. Earth and Planetary Science Letters, 351-352, 270280. doi: http://dx.doi.org/10.1016/j.epsl.2012.07.004

Allen, K. A., Hönisch, B., Eggins, S. M., Yu, J., Spero, H. J., \& Elderfield, H. (2011). Controls on boron incorporation in cultured tests of the planktic foraminifer Orbulina universa. Earth and Planetary Science Letters, 309(3-4), 291-301. doi: http://dx.doi.org/10.1016/j.eps1.2011.07.010

Bentov, S., Brownlee, C., \& Erez, J. (2009). The role of seawater endocytosis in the biomineralization process in calcareous foraminifera. Proceedings of the National Academy of Sciences, 106(51), 21500-21504. doi: 10.1073/pnas.0906636106

Bentov, S., \& Erez, J. (2005). Novel observations on biomineralization processes in foraminifera and implications for $\mathrm{Mg} / \mathrm{Ca}$ ratio in the shells. Geology, 33(11), 841-844. doi: $10.1130 / \mathrm{g} 21800.1$

Bijma, J., Spero, H. J., \& Lea, D. W. (1999). Reassessing Foraminiferal Stable Isotope Geochemistry: Impact of the Oceanic Carbonate System (Experimental Results). In G. Fischer \& G. Wefer (Eds.), Use of Proxies in Paleoceanography (pp. 489-512): Springer Berlin Heidelberg.

Boyle, E. A. (1995). Limits on benthic foraminiferal chemical analyses as precise measures of environmental properties. The Journal of Foraminiferal Research, 25(1), 4-13.

Branson, O., Kaczmarek, K., Redfern, S. A. T., Misra, S., Langer, G., Tyliszczak, T., . . . Elderfield, H. (2015). The coordination and distribution of B in foraminiferal calcite. Earth and Planetary Science Letters, 416, 67-72. doi: http://dx.doi.org/10.1016/j.eps1.2015.02.006

Burton, E. A., \& Walter, L. M. (1987). Relative precipitation rates of aragonite and Mg calcite from seawater: Temperature or carbonate ion control? Geology, 15(2), 111114. doi: 10.1130/0091-7613(1987)15<111:rproaa>2.0.co;2

Butterworth, S. (1930). On the theory of filter amplifiers. Wireless Engineer, 7(6), 536-541.

de Nooijer, L. J., Spero, H. J., Erez, J., Bijma, J., \& Reichart, G. J. (2014). Biomineralization in perforate foraminifera. Earth-Science Reviews, 135, 48-58. doi: http://dx.doi.org/10.1016/j.earscirev.2014.03.013

de Nooijer, L. J., Toyofuku, T., \& Kitazato, H. (2009). Foraminifera promote calcification by elevating their intracellular pH. Proceedings of the National Academy of Sciences, 106(36), 15374-15378. doi: 10.1073/pnas.0904306106

DePaolo, D. J. (2011). Surface kinetic model for isotopic and trace element fractionation during precipitation of calcite from aqueous solutions. Geochimica et Cosmochimica Acta, 75(4), 1039-1056. doi: http://dx.doi.org/10.1016/j.gca.2010.11.020

Djogic, R., Sipos, L., \& Branica, M. (1986). Characterization of uranium(VI) in seawater. Journal Name: Limnol. Oceanogr.; (United States); Journal Volume: 31:5, Medium: X; Size: Pages: 1122-1131. 
Dromgoole, E. L., \& Walter, L. M. (1990). Iron and manganese incorporation into calcite: Effects of growth kinetics, temperature and solution chemistry. Chemical Geology, 81(4), 311-336. doi: http://dx.doi.org/10.1016/0009-2541(90)90053-A

Dueñas-Bohórquez, A., da Rocha, R. E., Kuroyanagi, A., Bijma, J., \& Reichart, G.-J. (2009). Effect of salinity and seawater calcite saturation state on $\mathrm{Mg}$ and $\mathrm{Sr}$ incorporation in cultured planktonic foraminifera. Marine Micropaleontology, 73(3-4), 178-189. doi: http://dx.doi.org/10.1016/j.marmicro.2009.09.002

Eggins, S., De Deckker, P., \& Marshall, J. (2003). Mg/Ca variation in planktonic foraminifera tests: implications for reconstructing palaeo-seawater temperature and habitat migration. Earth and Planetary Science Letters, 212(3-4), 291-306. doi: http://dx.doi.org/10.1016/S0012-821X(03)00283-8

Eggins, S. M., Sadekov, A., \& De Deckker, P. (2004). Modulation and daily banding of $\mathrm{Mg} / \mathrm{Ca}$ in Orbulina universa tests by symbiont photosynthesis and respiration: a complication for seawater thermometry? Earth and Planetary Science Letters, 225(34), 411-419. doi: http://dx.doi.org/10.1016/j.eps1.2004.06.019

Erez, J. (2003). The Source of Ions for Biomineralization in Foraminifera and Their Implications for Paleoceanographic Proxies. Reviews in Mineralogy and Geochemistry, 54(1), 115-149. doi: 10.2113/0540115

Fantle, M. S., \& Tipper, E. T. (2014). Calcium isotopes in the global biogeochemical Ca cycle: Implications for development of a Ca isotope proxy. Earth-Science Reviews, 129, 148-177. doi: http://dx.doi.org/10.1016/j.earscirev.2013.10.004

Fujiki, T., Takagi, H., Kimoto, K., Kurasawa, A., Yuasa, T., \& Mino, Y. (2014). Assessment of algal photosynthesis in planktic foraminifers by fast repetition rate fluorometry. Journal of Plankton Research, 36(6), 1403-1407. doi: 10.1093/plankt/fbu083

Gabitov, R. I., \& Watson, E. B. (2006). Partitioning of strontium between calcite and fluid. Geochemistry, Geophysics, Geosystems, 7(11), n/a-n/a. doi: 10.1029/2005GC001216

Glas, M. S., Langer, G., \& Keul, N. (2012). Calcification acidifies the microenvironment of a benthic foraminifer (Ammonia sp.). Journal of Experimental Marine Biology and Ecology, 424-425, 53-58. doi: http://dx.doi.org/10.1016/j.jembe.2012.05.006

Gussone, N., Eisenhauer, A., Heuser, A., Dietzel, M., Bock, B., Böhm, F., . . Nägler, T. F. (2003). Model for kinetic effects on calcium isotope fractionation $(\delta 44 \mathrm{Ca})$ in inorganic aragonite and cultured planktonic foraminifera. Geochimica et Cosmochimica Acta, 67(7), 1375-1382. doi: http://dx.doi.org/10.1016/S00167037(02)01296-6

Hemming, N. G., \& Hanson, G. N. (1992). Boron isotopic composition and concentration in modern marine carbonates. Geochimica et Cosmochimica Acta, 56(1), 537-543. doi: http://dx.doi.org/10.1016/0016-7037(92)90151-8

Henehan, M. J., Rae, J. W. B., Foster, G. L., Erez, J., Prentice, K. C., Kucera, M., . . Elliott, T. (2013). Calibration of the boron isotope proxy in the planktonic foraminifera Globigerinoides ruber for use in palaeo-CO2 reconstruction. Earth and Planetary Science Letters, 364, 111-122. doi: http://dx.doi.org/10.1016/j.eps1.2012.12.029

Hershey, J. P., Fernandez, M., Milne, P. J., \& Millero, F. J. (1986). The ionization of boric acid in $\mathrm{NaCl}, \mathrm{Na} \square \mathrm{Ca} \square \mathrm{Cl}$ and $\mathrm{Na} \square \mathrm{Mg} \square \mathrm{Cl}$ solutions at $25^{\circ} \mathrm{C}$. Geochimica et Cosmochimica Acta, 50(1), 143-148. doi: http://dx.doi.org/10.1016/00167037(86)90059-1

Jones, E., Oliphant, T., \& Peterson, P. (2001). Open source scientific tools for Python: Scipy. Kaczmarek, K., Langer, G., Nehrke, G., Horn, I., Misra, S., Janse, M., \& Bijma, J. (2015). Boron incorporation in the foraminifer Amphistegina lessonii under a decoupled carbonate chemistry. Biogeosciences, 12(6), 1753-1763. doi: 10.5194/bg-12-17532015 
602

603

604

605

606

607

608

609

610

611

612

613

614

615

616

617

618

619

620

621

622

623

624

625

626

627

628

629

630

631

632

633

634

Kısakürek, B., Eisenhauer, A., Böhm, F., Garbe-Schönberg, D., \& Erez, J. (2008). Controls on shell $\mathrm{Mg} / \mathrm{Ca}$ and $\mathrm{Sr} / \mathrm{Ca}$ in cultured planktonic foraminiferan, Globigerinoides ruber (white). Earth and Planetary Science Letters, 273(3-4), 260-269. doi: http://dx.doi.org/10.1016/j.eps1.2008.06.026

Kisakürek, B., Eisenhauer, A., Böhm, F., Hathorne, E. C., \& Erez, J. (2011). Controls on calcium isotope fractionation in cultured planktic foraminifera, Globigerinoides ruber and Globigerinella siphonifera. Geochimica et Cosmochimica Acta, 75(2), 427-443. doi: http://dx.doi.org/10.1016/j.gca.2010.10.015

Köhler-Rink, S., \& Kühl, M. (2005). The chemical microenvironment of the symbiotic planktonic foraminifer Orbulina universa. Marine Biology Research, 1(1), 68-78. doi: 10.1080/17451000510019015

Lea, D. W., Martin, P. A., Chan, D. A., \& Spero, H. J. (1995). Calcium uptake and calcification rate in the planktonic foraminifer Orbulina universa. The Journal of Foraminiferal Research, 25(1), 14-23. doi: 10.2113/gsjfr.25.1.14

Lea, D. W., Mashiotta, T. A., \& Spero, H. J. (1999). Controls on magnesium and strontium uptake in planktonic foraminifera determined by live culturing. Geochimica et Cosmochimica Acta, 63(16), 2369-2379. doi: http://dx.doi.org/10.1016/S00167037(99)00197-0

Longerich, H. P. (1996). Laser ablation inductively coupled plasma mass spectrometric transient signal data acquisition and analyte concentration calculation. Journal of Analytical Atomic Spectrometry, 11, 899-904.

Lorens, R. B. (1981). Sr, Cd, Mn and Co distribution coefficients in calcite as a function of calcite precipitation rate. Geochimica et Cosmochimica Acta, 45(4), 553-561. doi: http://dx.doi.org/10.1016/0016-7037(81)90188-5

McCrea, J. M. (1950). On the Isotopic Chemistry of Carbonates and a Paleotemperature Scale. The Journal of Chemical Physics, 18(6), 849-857. doi: doi:http://dx.doi.org/10.1063/1.1747785

Millero, F. J. (1974). Seawater as a multicomponent electrolyte solution. The sea, 5, 3-80.

Morse, J. W., \& Bender, M. L. (1990). Partition coefficients in calcite: Examination of factors influencing the validity of experimental results and their application to natural systems. Chemical Geology, 82, 265-277. doi: http://dx.doi.org/10.1016/00092541(90)90085-L

Nielsen, L. C., DePaolo, D. J., \& De Yoreo, J. J. (2012). Self-consistent ion-by-ion growth model for kinetic isotopic fractionation during calcite precipitation. Geochimica et Cosmochimica Acta, 86, 166-181. doi: http://dx.doi.org/10.1016/j.gca.2012.02.009

Pak, D. K., Lea, D. W., \& Kennett, J. P. (2004). Seasonal and interannual variation in Santa Barbara Basin water temperatures observed in sediment trap foraminiferal $\mathrm{Mg} / \mathrm{Ca}$. Geochemistry, Geophysics, Geosystems, 5(12), n/a-n/a. doi: 10.1029/2004GC000760

Reeder, R. J., Nugent, M., Lamble, G. M., Tait, C. D., \& Morris, D. E. (2000). Uranyl Incorporation into Calcite and Aragonite: XAFS and Luminescence Studies. Environmental Science \& Technology, 34(4), 638-644. doi: 10.1021/es990981j

Rink, S., Kühl, M., Bijma, J., \& Spero, H. J. (1998). Microsensor studies of photosynthesis and respiration in the symbiotic foraminifer Orbulina universa. Marine Biology, 131(4), 583-595. doi: 10.1007/s002270050350

Russell, A. D., Hönisch, B., Spero, H. J., \& Lea, D. W. (2004). Effects of seawater carbonate ion concentration and temperature on shell $\mathrm{U}, \mathrm{Mg}$, and $\mathrm{Sr}$ in cultured planktonic foraminifera. Geochimica et Cosmochimica Acta, 68(21), 4347-4361. doi: http://dx.doi.org/10.1016/j.gca.2004.03.013 
Sadekov, A. Y., Eggins, S. M., \& De Deckker, P. (2005). Characterization of $\mathrm{Mg} / \mathrm{Ca}$ distributions in planktonic foraminifera species by electron microprobe mapping. Geochemistry, Geophysics, Geosystems, 6(12), n/a-n/a. doi: 10.1029/2005GC000973

Sanyal, A., Hemming, N. G., Broecker, W. S., Lea, D. W., Spero, H. J., \& Hanson, G. N. (1996). Oceanic $\mathrm{pH}$ control on the boron isotopic composition of foraminifera: Evidence from culture experiments. Paleoceanography, 11(5), 513-517. doi: 10.1029/96PA01858

Sanyal, A., Nugent, M., Reeder, R. J., \& Bijma, J. (2000). Seawater pH control on the boron isotopic composition of calcite: evidence from inorganic calcite precipitation experiments. Geochimica et Cosmochimica Acta, 64(9), 1551-1555. doi: http://dx.doi.org/10.1016/S0016-7037(99)00437-8

Spero, H. J. (1988). Ultrastructural examination of chamber morphogenesis and biomineralization in the planktonic foraminiferOrbulina universa. Marine Biology, 99(1), 9-20. doi: 10.1007/BF00644972

Spero, H. J., Eggins, S. M., Russell, A. D., Vetter, L., Kilburn, M. R., \& Hönisch, B. (2015). Timing and mechanism for intratest $\mathrm{Mg} / \mathrm{Ca}$ variability in a living planktic foraminifer. Earth and Planetary Science Letters, 409, 32-42. doi: http://dx.doi.org/10.1016/j.epsl.2014.10.030

Spero, H. J., \& Parker, S. L. (1985). Photosynthesis in the symbiotic planktonic foraminifer Orbulina universa, and its potential contribution to oceanic primary productivity. The Journal of Foraminiferal Research, 15(4), 273-281. doi: 10.2113/gsjfr.15.4.273

Swart, P. K., \& Hubbard, J. A. E. B. (1982). Uranium in scleractinian coral skeletons. Coral Reefs, 1(1), 13-19. doi: 10.1007/BF00286535

Takagi, H., Kimoto, K., Fujiki, T., Kurasawa, A., Moriya, K., \& Hirano, H. (2016). Ontogenetic dynamics of photosymbiosis in cultured planktic foraminifers revealed by fast repetition rate fluorometry. Marine Micropaleontology, 122, 44-52. doi: http://dx.doi.org/10.1016/j.marmicro.2015.10.003

Tang, J., Köhler, S. J., \& Dietzel, M. (2008). Sr2+/Ca2+ and 44Ca/40Ca fractionation during inorganic calcite formation: I. Sr incorporation. Geochimica et Cosmochimica Acta, 72(15), 3718-3732. doi: http://dx.doi.org/10.1016/j.gca.2008.05.031

Tesoriero, A. J., \& Pankow, J. F. (1996). Solid solution partitioning of Sr2+, Ba2+, and Cd2+ to calcite. Geochimica et Cosmochimica Acta, 60(6), 1053-1063. doi: http://dx.doi.org/10.1016/0016-7037(95)00449-1

Uchikawa, J., Penman, D. E., Zachos, J. C., \& Zeebe, R. E. (2015). Experimental evidence for kinetic effects on $\mathrm{B} / \mathrm{Ca}$ in synthetic calcite: Implications for potential $\mathrm{B}(\mathrm{OH}) 4-$ and $\mathrm{B}(\mathrm{OH}) 3$ incorporation. Geochimica et Cosmochimica Acta, 150, 171-191. doi: http://dx.doi.org/10.1016/j.gca.2014.11.022

Urey, H. C., Lowenstam, H. A., Epstein, S., \& McKinney, C. R. (1951). Measurement of paleotemperatures and temperatures of the upper Cretaceous of England, Denmark and the Southeastern United States. Geological Society of America Bulletin, 62(4), 399-416. doi: 10.1130/0016-7606(1951)62[399:mopato]2.0.co;2

Van Heuven, S., Pierrot, D., Lewis, E., \& Wallace, D. (2011). MATLAB Program Developed for CO 2 System Calculations. ORNL/CDIAC-105b. Carbon Dioxide Information Analysis Center, Oak Ridge National Laboratory, US Department of Energy, Oak Ridge, Tennessee.

Walker, R. A. (2004). Photosynthesis and respiration in five species of benthic foraminifera that host algal symbionts. Graduate Theses and Dissertations, University of South Florida. doi: http://scholarcommons.usf.edu/etd/1287 
683

684

685

686

687

688

689

690

691

692

693

694

695

696

697

698

699

700

701

702

703

704

705

706

707

708
Weiner, S., \& Dove, P. M. (2003). An Overview of Biomineralization Processes and the Problem of the Vital Effect. Reviews in Mineralogy and Geochemistry, 54(1), 1-29. doi: 10.2113/0540001

Wolf-Gladrow, D., \& Riebesell, U. (1997). Diffusion and reactions in the vicinity of plankton: A refined model for inorganic carbon transport. Marine Chemistry, 59(1-2), 17-34. doi: http://dx.doi.org/10.1016/S0304-4203(97)00069-8

Wolf-Gladrow, D. A., Bijma, J., \& Zeebe, R. E. (1999). Model simulation of the carbonate chemistry in the microenvironment of symbiont bearing foraminifera. Marine Chemistry, 64(3), 181-198. doi: http://dx.doi.org/10.1016/S0304-4203(98)00074-7

Wolthers, M., Nehrke, G., Gustafsson, J. P., \& Van Cappellen, P. (2012). Calcite growth kinetics: Modeling the effect of solution stoichiometry. Geochimica et Cosmochimica Acta, 77, 121-134. doi: http://dx.doi.org/10.1016/j.gca.2011.11.003

Yu, J., Elderfield, H., \& Hönisch, B. (2007). B/Ca in planktonic foraminifera as a proxy for surface seawater pH. Paleoceanography, 22(2), n/a-n/a. doi: 10.1029/2006PA001347

Zeebe, R. E., Bijma, J., \& Wolf-Gladrow, D. A. (1999). A diffusion-reaction model of carbon isotope fractionation in foraminifera. Marine Chemistry, 64(3), 199-227. doi: http://dx.doi.org/10.1016/S0304-4203(98)00075-9

Zeebe, R. E., \& Sanyal, A. (2002). Comparison of two potential strategies of planktonic foraminifera for house building: $\mathrm{Mg} 2+$ or $\mathrm{H}+$ removal? Geochimica et Cosmochimica Acta, 66(7), 1159-1169. doi: http://dx.doi.org/10.1016/S0016-7037(01)00852-3

Zeebe, R. E., Wolf-Gladrow, D. A., Bijma, J., \& Hönisch, B. (2003). Vital effects in foraminifera do not compromise the use of $\delta 11 \mathrm{~B}$ as a paleo-pH indicator: Evidence from modeling. Paleoceanography, 18(2). doi: 10.1029/2003PA000881 
711 Fig. 1. A schematic cross section through $O$. universa that distinguishes the ambient seawater

712 from the chemical microenvironment and the internal calcification environment. The

713 chemical microenvironment is modified from the external seawater on a diurnal timescale by

714 symbiont photosynthetic activity, respiration and calcification. Seawater might be endocytosed and transported from the chemical microenvironment to the calcification environment, or there might be more open communication between the calcification environment and the chemical microenvironment. Adapted from Erez, (2003) and de Nooijer et al. (2014).

Fig. 2. a) Seawater carbonate chemistry changes predicted to occur immediately adjacent to the shell wall of $O$. universa over multiple diurnal cycles. The model results shown are calculated using the diffusion-reaction model of Zeebe et al. (2003) and fit to a sinusoidal curve that matches the full range of chemistry calculated for light and dark conditions assuming ambient seawater conditions, $\mathrm{pH}_{\text {TOTAL }} \approx 8.00 \mathrm{DIC} \approx 2000 \mu \mathrm{mol} \mathrm{kg}^{-1}$, and a foraminifer shell radius of $250 \mu \mathrm{m}$. Rates of photosynthesis, respiration and calcification were fixed at 10, 2 and $3 \mathrm{nmol} \mathrm{C} \mathrm{h}^{-1}$ in the light, and 0,2 and $1 \mathrm{nmol} \mathrm{C} \mathrm{h}^{-1}$ in the dark, following Zeebe et al. (2003). b) The diurnal changes in microenvironment carbonate chemistry are converted to changes in the $\mathrm{B} / \mathrm{Ca}$ (solid line) and $\mathrm{U} / \mathrm{Ca}$ (dashed line) composition of shell calcite precipitated by $O$. universa using published bulk shell proxy calibrations for B/Ca (Allen et al., 2011) and U/Ca ratios (Russell et al., 2004).

732 Fig. 3. LA-ICP-MS transects through individual $O$. universa shells grown in culture experiments. $\mathrm{Mg} / \mathrm{Ca}$ (black), $\mathrm{B} / \mathrm{Ca}$ (blue) and $\mathrm{U} / \mathrm{Ca}$ (red) profiles were measured from the 
734 inside through to the outside surface of the shell wall. $\mathrm{Mg} / \mathrm{Ca}$ banding provides a reference for day-night calcification (Spero et al., 2015), as demonstrated in dark/light annotations (e.g. panel (a)), the bands are numbered for each day after sphere formation. In general, $\mathrm{B} / \mathrm{Ca}$ bands are broadly out of phase with $\mathrm{Mg} / \mathrm{Ca}$ bands. Where present, $\mathrm{U} / \mathrm{Ca}$ bands are broadly in phase with $\mathrm{Mg} / \mathrm{Ca}$ bands (profiles a-d). $\mathrm{U} / \mathrm{Ca}$ is also notable for often being elevated at the POS. Profiles are grouped by the experiment seawater type and labelled with the foraminifer identification number. The small dots represent the measurement noise associated with each $\mathrm{TE} / \mathrm{Ca}$ profile. Note that the sample in panel (g) was placed into high $\mathrm{pH}$ experimental seawater only after it had produced a thinly calcified adult sphere. As a result, its shell composition near the POS has low $\mathrm{B} / \mathrm{Ca}(<500 \mu \mathrm{mol} / \mathrm{mol})$ and low $\mathrm{U} / \mathrm{Ca}$, which reflects the lower B and $\mathrm{U}$ concentrations in natural seawater compared to the experimental seawater.

Fig. 4. LA-ICP-MS depth profiles were de-trended using a Butterworth bandpass Fourier

filter, in order to isolate banding patterns from low frequency trends and from high frequency noise. Plotted are the de-trended depth profiles of $\mathrm{Mg} / \mathrm{Ca}$ (black), $\mathrm{B} / \mathrm{Ca}$ (blue) and $\mathrm{U} / \mathrm{Ca}$ (red) through shells of $O$. universa. Profiles are displayed from the inside through to the outside surface of the shell wall. The sample number of each foraminifer is noted in the top right corner.

Fig. 5. LA-ICP-MS profiles of $\mathrm{Mg} / \mathrm{Ca}$ (black), $\mathrm{Sr} / \mathrm{Ca}$ (orange) and $\mathrm{Mn} / \mathrm{Ca}$ (purple) through chamber walls of individual $O$. univers $a$ cultured in this study (refer to the caption of Fig. 3 for the details of plot labelling). Note the timing of $\mathrm{Mn} / \mathrm{Ca}$ variations with $\mathrm{Mg} / \mathrm{Ca}$ banding in low DIC experiments, (a-b). Sr/Ca ratios tend to be higher on the outside of the POS relative to the inside. 
760 Fig. 6. Bulk shell $\mathrm{Mg} / \mathrm{Ca}, \mathrm{Sr} / \mathrm{Ca}, \mathrm{B} / \mathrm{Ca}, \mathrm{Mn} / \mathrm{Ca}$ and $\mathrm{U} / \mathrm{Ca}$ ratio values of O. universa vs.

761 seawater carbonate system parameters (circles). Error bars $(1 \sigma)$ reflect variability of 762 individual shell compositions (crosses) grown within each experiment. Arrows indicate 763 correction of shell $\mathrm{B} / \mathrm{Ca}, \mathrm{Mn} / \mathrm{Ca}$ and $\mathrm{U} / \mathrm{Ca}$ compositions to account for the $2.6 \mathrm{x}$ lower $764[\mathrm{~B}]_{\mathrm{T}}, 4.7 \mathrm{x}$ higher $[\mathrm{Mn}]_{\mathrm{T}}$, and 3.1x lower $[\mathrm{U}]_{\mathrm{T}}$ of the low DIC experiment (see text for details). 765 The adjustment of $[\mathrm{B}]_{\mathrm{T}}$ and $[\mathrm{U}]_{\mathrm{T}}$ of the low DIC experiment up to the elevated $[\mathrm{B}]_{\mathrm{T}}$ and $766[\mathrm{U}]_{\mathrm{T}}$ of the other experiments is made to emphasize the elevated boron and uranium 767 concentrations we have used in these experiments. Thick black lines show significant linear 768 regression fits obtained between bulk shell trace element to calcium ratios and the 769 various seawater carbonate system parameters. Grey lines show scaled relationships for bulk 770 shell compositions reported by Allen et al. (2011) for B/Ca, and by Russell et al. (2004) for $\mathrm{U} / \mathrm{Ca}$, and the relationship between $\mathrm{Mg} / \mathrm{Ca}$ with $\left[\mathrm{CO}_{3}{ }^{2-}\right]$ and $\mathrm{pH}$ from Russell et al. (2004).

773 Fig. 7. Variation of apparent partition coefficients, $\mathrm{K}_{\mathrm{D} \_\mathrm{B} / \mathrm{Ca}}, \mathrm{K}_{\mathrm{D} \_\mathrm{Mg} / \mathrm{Ca}}, \mathrm{K}_{\mathrm{D} \_\mathrm{Mn} / \mathrm{Ca}}, \mathrm{K}_{\mathrm{D} \_\mathrm{Sr} / \mathrm{Ca}}$, and

$774 \mathrm{~K}_{\mathrm{D} \_\mathrm{U} / \mathrm{Ca}}$ with linear calcification rate (reported as $\log _{10}$ (Rate) in $\left.\mathrm{mol} \mathrm{m}^{-2} \mathrm{~s}^{-1}\right)$. Error bars $(1 \sigma)$ 775 reflect the variability of individual shell compositions and calcification rates in each experiment.

Fig. 8. De-trended (see text) and predicted $\mathrm{B} / \mathrm{Ca}$ (blue) and $\mathrm{U} / \mathrm{Ca}$ (red) from the inner shell

779 surface through to the outside of the shell wall in individual $O$. universa from culture experiments. Profiles are grouped by the experiment seawater type and labelled with the

781 foraminifer identification number. In these plots the axis scales for $\mathrm{B} / \mathrm{Ca}$ and $\mathrm{U} / \mathrm{Ca}$ are

782 consistent throughout, to enable comparison of shell responses to different seawater

783 chemistries and modelling predictions. Panels (i) and (j) show examples of changes in 
784 predicted $\mathrm{B} / \mathrm{Ca}$ and $\mathrm{U} / \mathrm{Ca}$ in sample \#2001, if calcification rate and photosynthesis inputs to

785 the diffusion-reaction model were doubled and halved. Also plotted in panels (i) and (j) is the

786 de-trended profile of sample \#2004.

787

788 Fig. 9. a) Bulk shell B/Ca of $O$. universa plotted as a function of seawater $\left[\mathrm{B}(\mathrm{OH})_{4}{ }^{-}\right] /\left[\mathrm{HCO}_{3}{ }^{-}\right]$

789 ratio. The low DIC experiments had $[\mathrm{B}]_{\mathrm{T}}$ less than half that of the other experiments,

790 requiring its measured bulk shell $\mathrm{B} / \mathrm{Ca}$ (open symbol) to be corrected using the $\mathrm{B} / \mathrm{Ca}$ -

$791\left[\mathrm{~B}(\mathrm{OH})_{4^{-}}\right]$relationship from Allen et al. (2011). b) A comparison of the B/Ca results from our

792 experiments and Allen et al. (2011), including a correction to the Allen et al. (2011) pH

793 experiments for $5 \mathrm{x}$ lower $[\mathrm{B}]_{\mathrm{T}}$. Error bars are $\pm 2 \mathrm{se}$. The trends between the data in this study

794 and those of Allen et al. (2011) are broadly comparable, the variability in our data is a result

795 of the small number of foraminifers used to produce mean shell B/Ca for each experiment. 
Table 1. Experimental conditions for foraminiferal culturing experiments, at $21.92 \pm 0.13^{\circ} \mathrm{C}$, and $33.3 \pm 0.2$ psu. $\mathrm{pH}_{\mathrm{TOTAL}}, \mathrm{DIC},\left[\mathrm{HCO}_{3}{ }^{-}\right],\left[\mathrm{CO}_{3}{ }^{2-}\right],\left[\mathrm{B}(\mathrm{OH})_{4}{ }^{-}\right]$and $\Omega_{\mathrm{Ca}}$ are calculated at $22^{\circ} \mathrm{C}$ from total alkalinity, $\mathrm{pH}_{\mathrm{NBS}}$ and $[\mathrm{B}]_{\mathrm{T}}$ measurements, made at $25^{\circ} \mathrm{C}$ using a modified version of the van Heuven et al. (2011) Matlab script, CO2SYS.m. Uncertainties associated with the calculated carbonate system parameters are attained with Monte Carlo simulations of CO2SYS using the measurement errors of the input total alkalinity $\left.(\leq 36 \mu \mathrm{mol} \mathrm{kg})^{-1}\right), \mathrm{pH}_{\mathrm{NBS}}(\leq 0.02)$ and $[\mathrm{B}]_{\mathrm{T}}(1.25 \%)$.

\begin{tabular}{|c|c|c|c|c|c|c|c|c|c|c|c|c|c|c|c|}
\hline \multirow[t]{2}{*}{$\begin{array}{c}\text { Experiment } \\
\text { Type }\end{array}$} & \multirow[t]{2}{*}{$\begin{array}{c}\text { No. } \\
\text { Forams }\end{array}$} & \multicolumn{2}{|c|}{$\mathbf{p H}_{\text {TOTAL }}$} & \multicolumn{2}{|l|}{ DIC } & \multicolumn{2}{|l|}{ Alklainity } & \multicolumn{2}{|l|}{$\mathrm{HCO}_{3}^{-}$} & \multicolumn{2}{|l|}{$\mathrm{CO}_{3}{ }^{2-}$} & \multirow{2}{*}{$\begin{array}{r}\mathrm{B}(\mathrm{OH})_{4}^{-} \\
\mu_{\mathrm{mol} \mathrm{kg}}^{-1}\end{array}$} & \multicolumn{3}{|c|}{$\Omega$} \\
\hline & & & $2 \sigma$ & $\mu \mathrm{mol} \mathrm{kg}{ }^{-1}$ & $2 \sigma$ & $\mu \mathrm{mol} \mathrm{kg}{ }^{-1}$ & $2 \sigma$ & $\mu \mathrm{mol} \mathrm{kg}{ }^{-1}$ & $2 \sigma$ & $\mu \mathrm{mol} \mathrm{kg}{ }^{-1}$ & $2 \sigma$ & & $2 \sigma$ & & $2 \sigma$ \\
\hline Low pH & 2 & 7.53 & 0.01 & 2047 & 34 & 2214 & 36 & 1943 & 33 & 61 & 2 & 148 & 5 & 1.5 & 0.1 \\
\hline Low DIC & 3 & 7.96 & 0.01 & 1026 & 5 & 1230 & 2 & 940 & 6 & 78 & 1 & 129 & 4 & 1.9 & 0.1 \\
\hline High DIC & 3 & 7.97 & 0.02 & 4019 & 29 & 4671 & 10 & 3673 & 37 & 315 & 11 & 362 & 16 & 7.8 & 0.3 \\
\hline High pH & 3 & 8.44 & 0.02 & 2135 & 39 & 3380 & 5 & 1696 & 44 & 434 & 10 & 802 & 33 & 10.7 & 0.3 \\
\hline
\end{tabular}


Click here to download Figuire: Figs_Feb2017.pdf

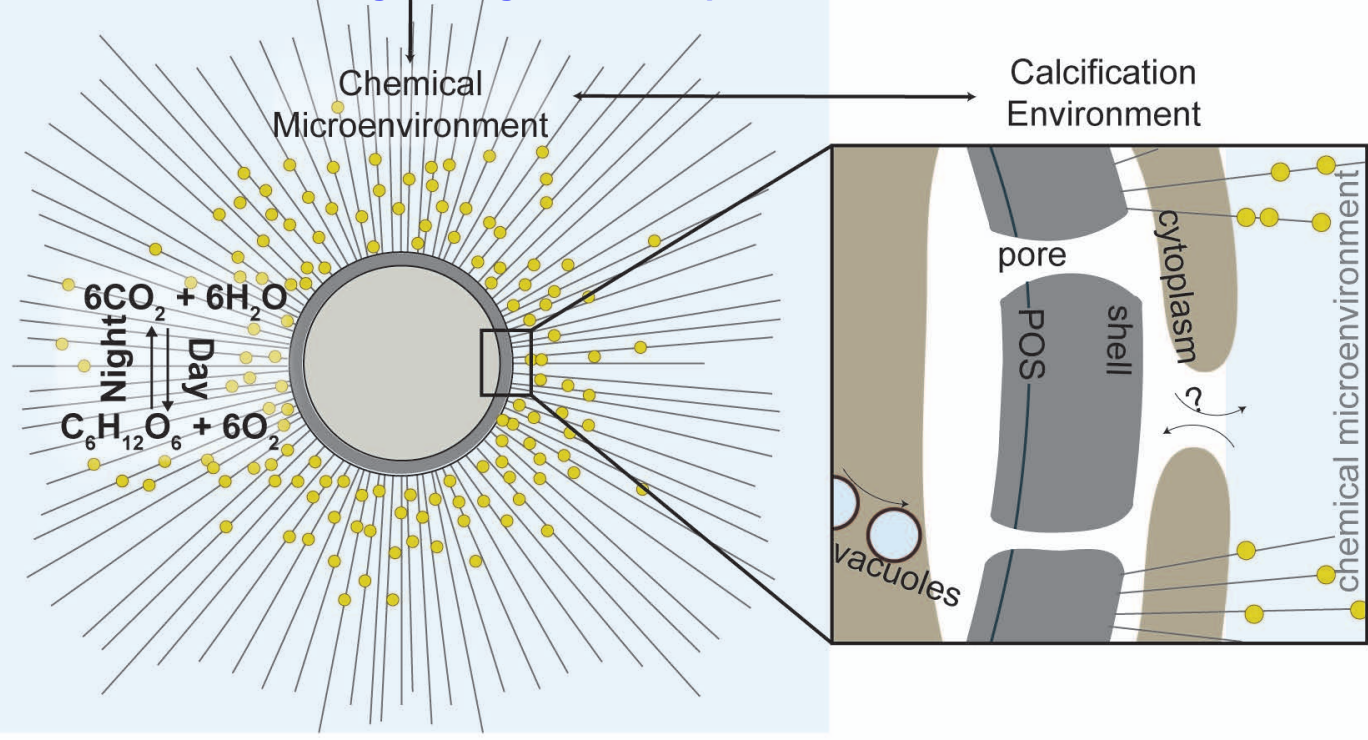

Fig 1.

Chemical

Microenvironment
Calcification 

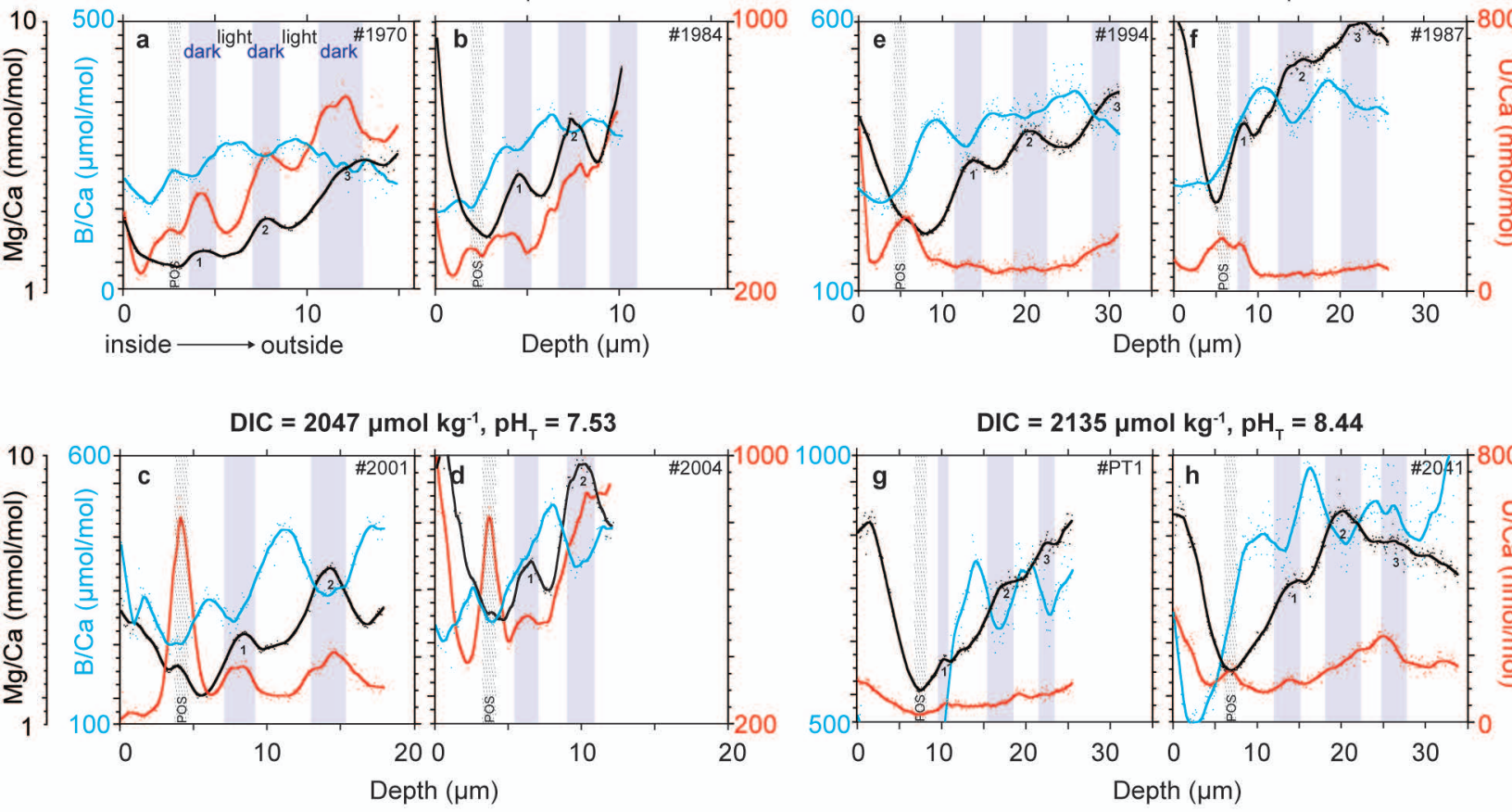

Fig 3. 
$\mathrm{DIC}=1026 \mu \mathrm{mol} \mathrm{kg}^{-1}, \mathrm{pH}_{\mathrm{T}}=7.96$

DIC $=4019 \mu \mathrm{mol} \mathrm{kg}^{-1}, \mathrm{pH}_{\mathrm{T}}=7.97$

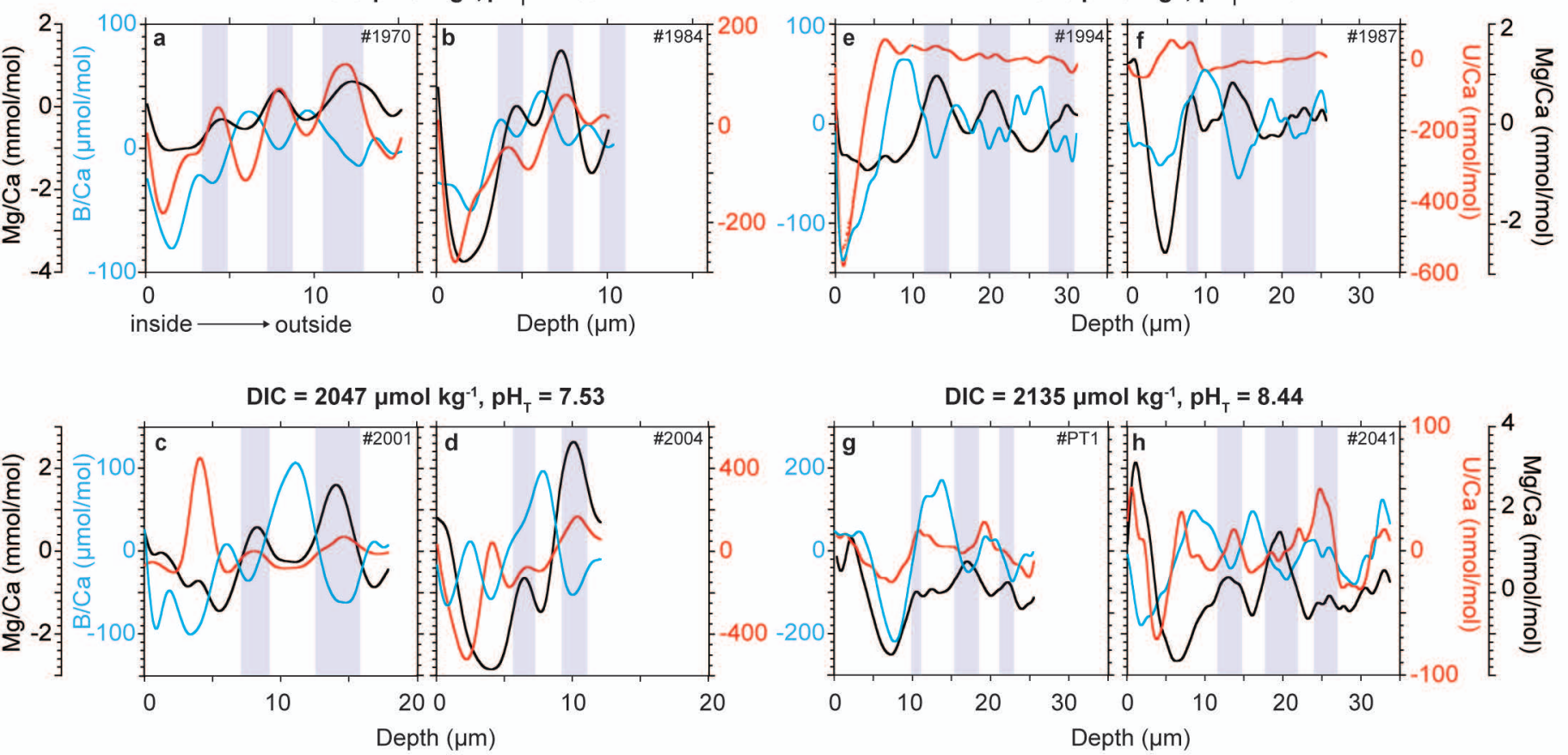

Fig 4. 
$\mathrm{DIC}=1026 \mu \mathrm{mol} \mathrm{kg}^{-1}, \mathrm{pH}_{\mathrm{T}}=7.96$

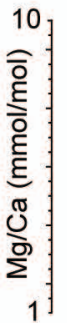

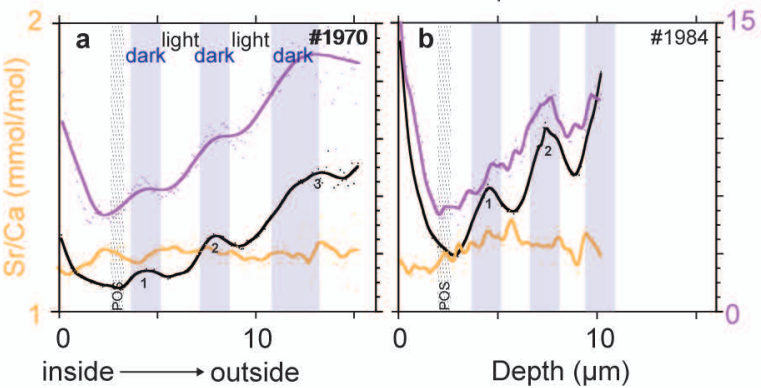

DIC $=2047 \mu \mathrm{mol} \mathrm{kg}^{-1}, \mathrm{pH}_{\mathrm{T}}=\mathbf{7 . 5 3}$
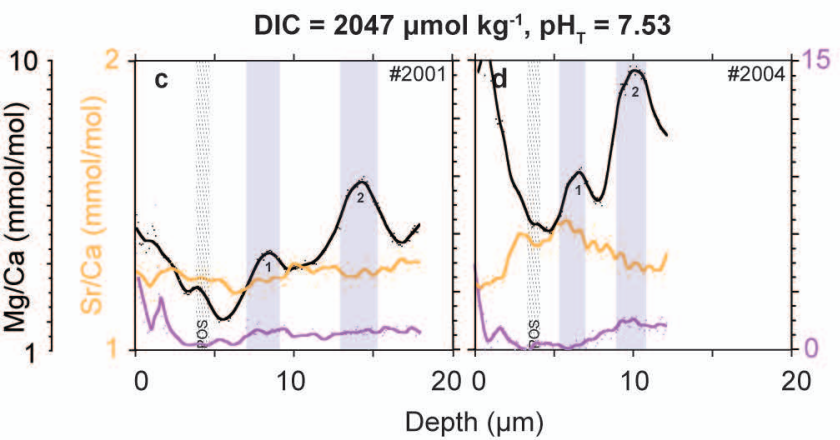

$\mathrm{DIC}=4019 \mu \mathrm{mol} \mathrm{kg}{ }^{-1}, \mathrm{pH}_{\mathrm{T}}=7.97$

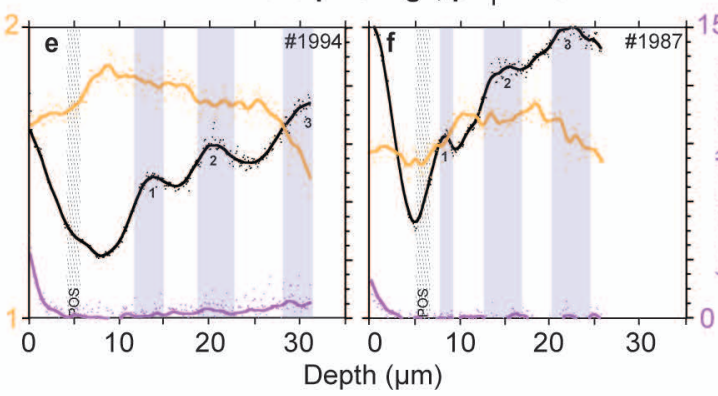

$$
\mathrm{DIC}=2135 \mu \mathrm{mol} \mathrm{kg}{ }^{-1}, \mathrm{pH}_{\mathrm{T}}=\mathbf{8 . 4 4}
$$

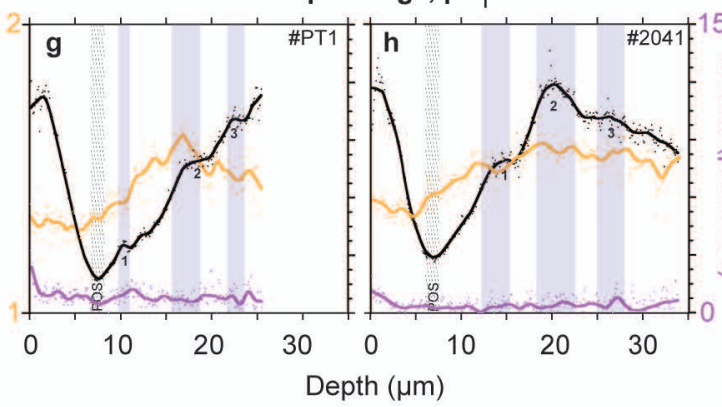

Fig 5. 
DIC $\left(\mu \mathrm{mol} \mathrm{kg}{ }^{-1}\right)$

$\mathrm{CO}_{3}{ }^{2-}\left(\mu \mathrm{mol} \mathrm{kg}^{-1}\right)$

$\mathrm{pH}_{\text {TOTAL }}$

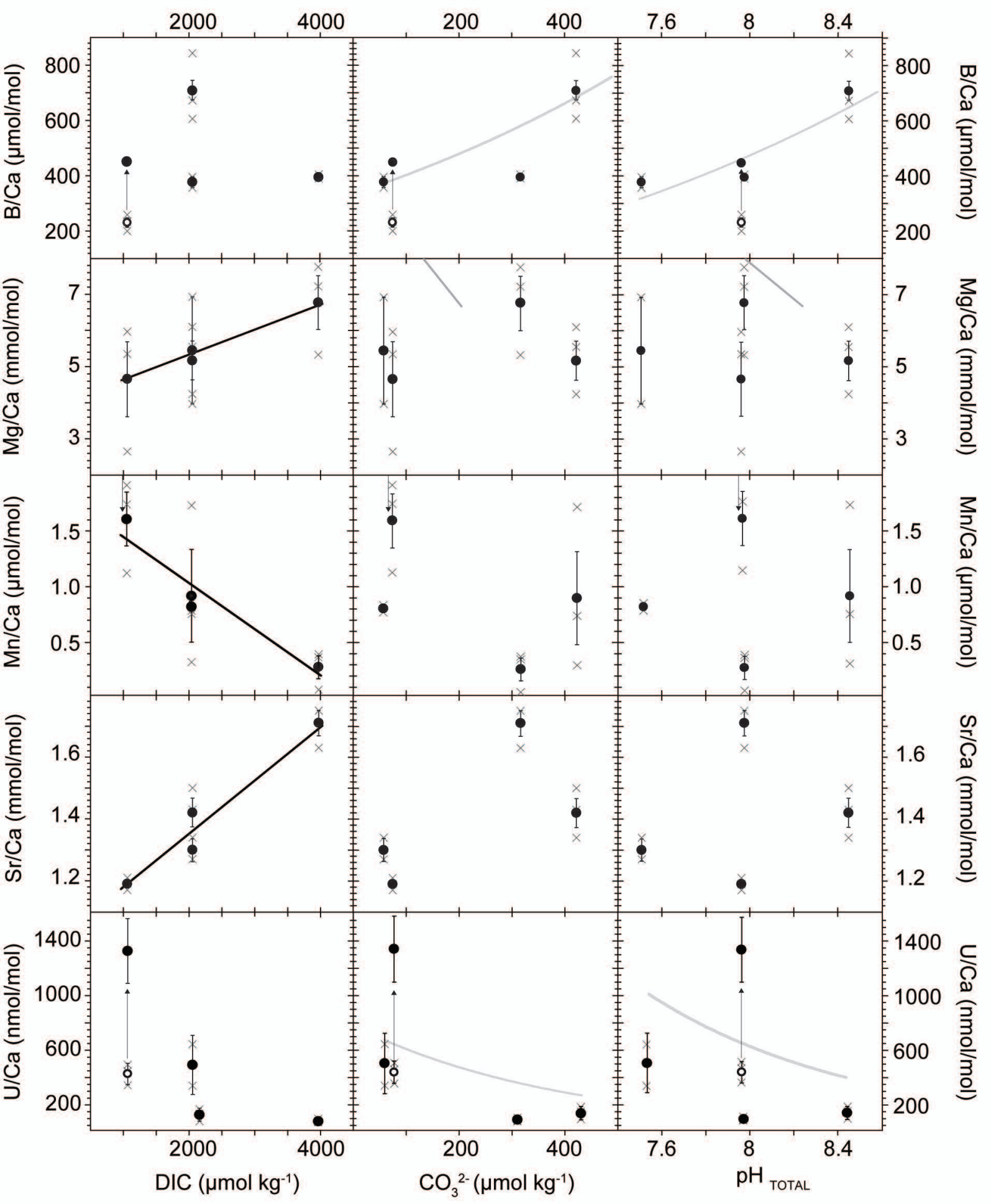

Fig 6. 


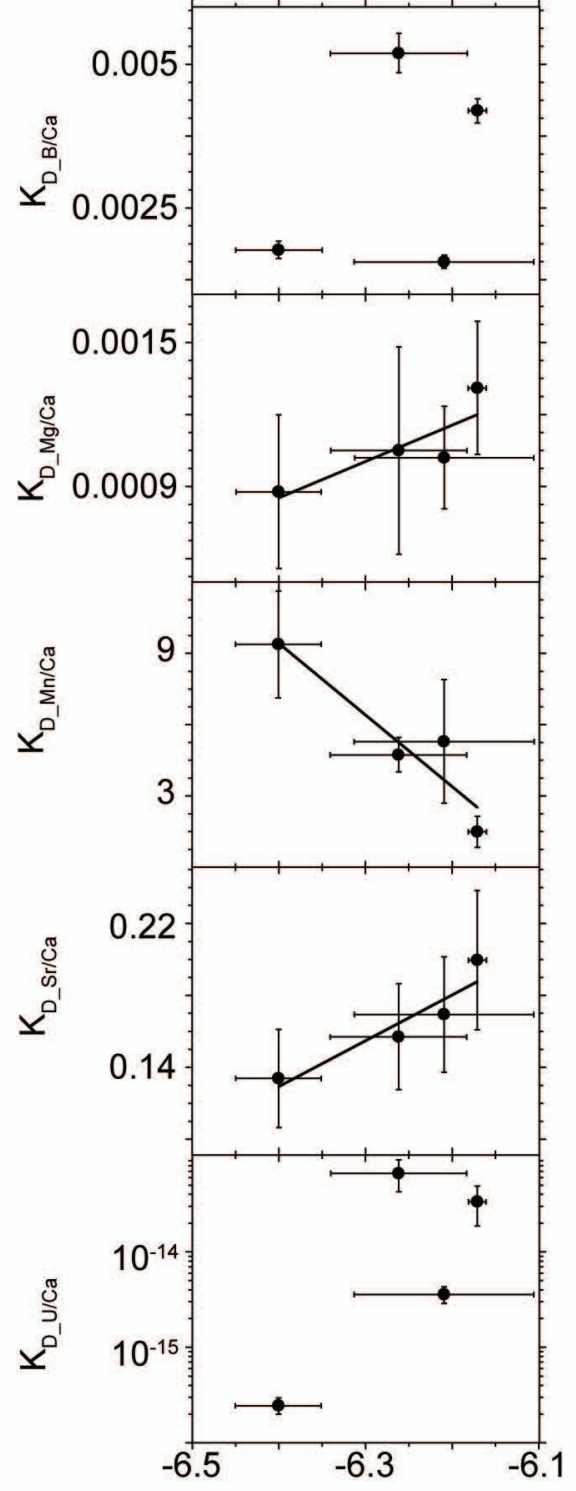

$\log _{10}$ (Rate) $\mathrm{molCaCO}_{3} \mathrm{~m}^{-2} \mathrm{~s}^{-1}$

Fig 7. 
DIC $=1026 \mu \mathrm{mol} \mathrm{kg}^{-1}, \quad$ DIC $=4019 \mu \mathrm{mol} \mathrm{kg}^{-1}, \quad$ DIC $=2135 \mu \mathrm{mol} \mathrm{kg}{ }^{-1}, \quad$ IIC $=2047 \mu \mathrm{mol} \mathrm{kg}-1$,

DIC $=2047 \mu \mathrm{mol}^{\mathbf{k g}} \mathbf{1}^{-1}$

$\mathrm{pH}_{\mathrm{T}}=7.96$
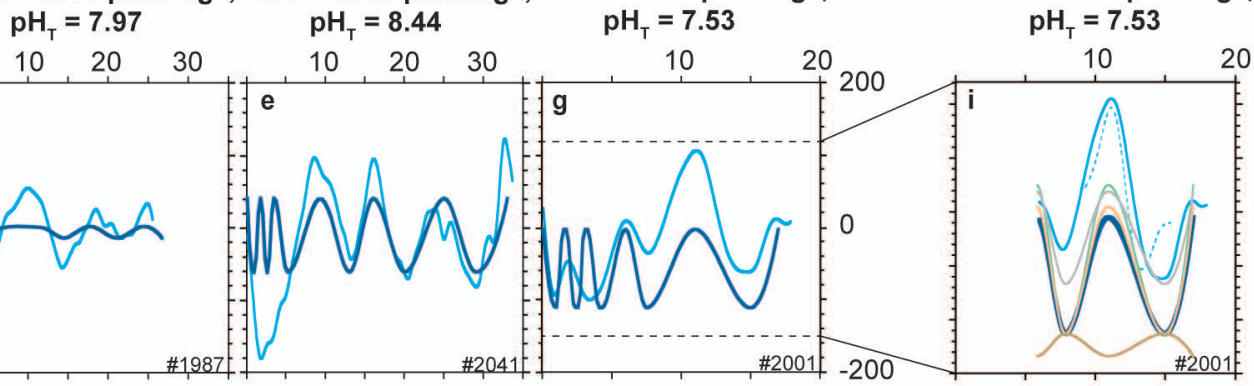

20
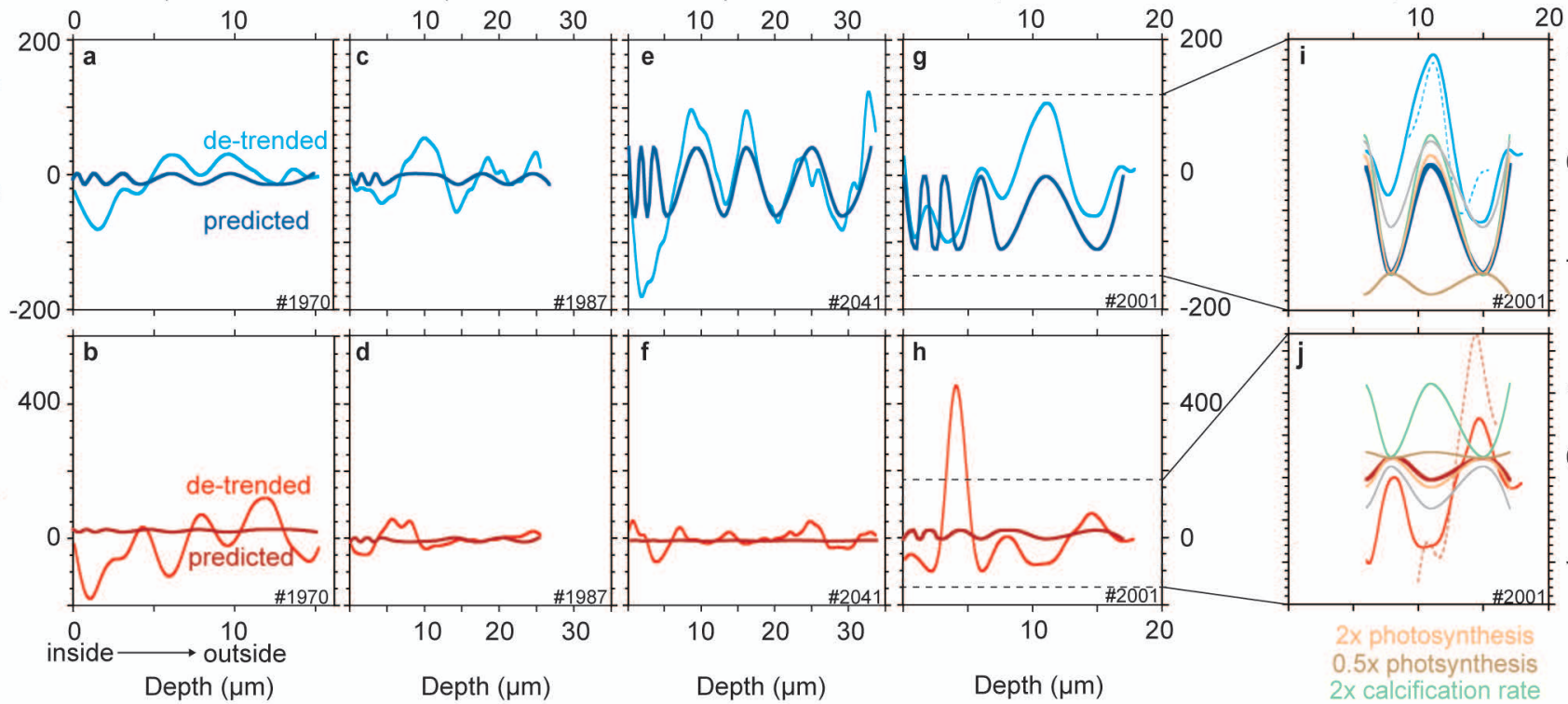

de-trended

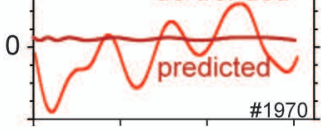

inside outside

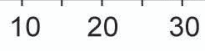

Depth $(\mu \mathrm{m})$

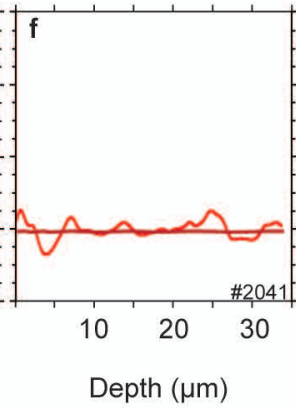

Depth $(\mu \mathrm{m})$
Depth $(\mu \mathrm{m})$ 2x photosynthesis

$0.5 x$ photsynthesis

$2 x$ calcification rate

$0.5 x$ calcification rate

-. - sample \#2004 
